\title{
Redox Site Confinement in Highly Unsymmetric Dimanganese Complexes
}

\author{
Tianlu Sheng, ${ }^{\dagger}$ Sebastian Dechert, ${ }^{\dagger}$ Isabella Hyla-Kryspin, ${ }^{*, \neq}$ Rainer F. Winter,\# and Franc Meyer ${ }^{*, \dagger}$ \\ Institut für Anorganische Chemie, Georg-August-Universität, Tammannstrasse 4, D-37077 \\ Göttingen, Germany, Organisch-Chemisches Institut, Universität Münster, Corrensstrasse 40, \\ D-48149 Münster, Germany, and Institut für Anorganische Chemie, Universität Stuttgart, \\ Pfaffenwaldring 55, D-70569 Stuttgart, Germany
}

Received March 10, 2005

\begin{abstract}
A set of highly preorganized pyrazolate-bridged dimanganese complexes $\mathrm{L}^{\mathrm{Mn}} \mathrm{MnX}$ have been prepared and structurally characterized. They can be described as hybrid organometallic/Werner-type systems that consist of a low-spin $\mathrm{CpMn}^{\prime}(\mathrm{CO})_{2}$ subunit $(\mathrm{Mn1})$ and a proximate tripodal tetradentate $\left\{\mathrm{N}_{4}\right\}$ binding pocket accommodating a high-spin $\mathrm{Mn}^{\|}$ion (Mn2), with $\mathrm{Mn} \cdots \mathrm{Mn}$ distances of $\sim 4.3 \AA$ and different coligands bound to Mn2. Density functional theory (DFT) calculations (both the hybrid B3LYP and the pure BP86 functionals and the all-electron basis sets 6-311G and 6-311G*) confirm that the valence $\alpha$ and $\beta$ Kohn-Sham molecular orbitals (MOs) of these mixed-valent Mn'Mn" compounds have predominant $\mathrm{Mn}(3 \mathrm{~d})$ character and an almost perfectly localized nature: all five unpaired electrons are essentially localized at the Werner-type Mn2, whereas Mn1 possesses an effective closed-shell structure with the MOs of highest energy centered there. One-electron oxidation occurs in a clean process at approximately $E_{1 / 2}$ $=-0.6 \mathrm{~V}$ (versus ferrocene/ferrocinium), giving the low-spin/high-spin $\mathrm{Mn}^{\|} \mathrm{Mn}^{\|}$species. UV/vis and IR spectroelectrochemistry as well as a detailed theoretical analysis reveal that the redox process takes place with strict site control at the organometallic subunit, while it does not significantly influence the spin and charge distribution on the Werner-type site. Positions and shifts of the $v(\mathrm{C} \equiv 0)$ absorptions are largely reproduced by the DFT calculations. These systems thus represent an exceptional example of the effect the unsymmetry of a dinucleating ligand scaffold has on the spin and charge distribution in homobimetallic complexes and might offer interesting prospects for the study of the cooperative effects of bimetallic arrays.
\end{abstract}

\section{Introduction}

Mixed-valence compounds containing metal ions in different oxidation states continue to attract strong interest. The mixed-valent character and electronic interaction between metal centers through or across bridging ligands are of fundamental relevance to areas ranging from electron transfer reactions in bioinorganic systems to electronic properties of materials. ${ }^{1,2}$ One direction of current research is defining the localized-to-delocalized transition in mixed-valence chem-

\footnotetext{
* To whom correspondence should be addressed. E-mail: franc.meyer@ chemie.uni-goettingen.de (F.M.); ihk@uni-muenster.de. (I.H.-K.).

$\dagger$ Georg-August-Universität Göttingen.

Universität Münster.

\# Universität Stuttgart.

(1) (a) Robin, M. B.; Day, P. Adv. Inorg. Chem. Radiochem. 1967, 10, 247-422. (b) Hush, N. S.; Coord. Chem. Rev. 1985, 64, 135-157. (c) Marcus, R. A.; Pure Appl. Chem. 1997, 69, 13-29.

(2) (a) Ward, M. D.; Chem. Soc. Rev. 1995, 121-134. (b) Vahrenkamp, H.; Geiss, A.; Richardson, G. N. J. Chem. Soc., Dalton Trans. 1997, 3643-3651.
}

10.1021/ic0503683 CCC: $\$ 30.25$ C 2005 American Chemical Society Published on Web 04/30/2005 istry, an area in which symmetric bimetallic systems with identical metal coordination spheres are investigated in most cases. ${ }^{3}$ On the other hand, the active sites of various binuclear (even homobinuclear) metallobiosites tend toward the other extreme and are highly unsymmetric with the metal centers residing in chemically different environments. ${ }^{4}$ Here the two metals have different accessibility and quite distinct roles in the overall catalytic process. A prominent case is the respiratory protein hemerythrin that contains in its active site both a five-coordinate iron where the $\mathrm{O}_{2}$ substrate binds and an adjacent six-coordinate iron that provides the second electron for dioxygen-to-hydroperoxide reduction. ${ }^{5}$ Such intriguing metal ion cooperativity, sometimes referred to as

(3) (a) Nelson, S. F. Chem.-Eur. J. 2000, 6, 581-588. (b) Demadis, K. D.; Hartshorn, C. M.; Meyer, T. J. Chem. Rev. 2001, 101, 26552685. (c) Brunschwig, B. S.; Creutz, C.; Sutin, N. Chem. Soc. Rev. 2002, 31, 168-184

(4) Belle, C.; Pierre, J.-L. Eur. J. Inorg. Chem. 2003, 4137-4146.

Inorganic Chemistry, Vol. 44, No. 11, 20053863 
one-site addition two-metal oxidation, has recently triggered the search for suitably designed unsymmetric bimetallic complexes that could lead to similar reactivity patterns in a synthetic system. ${ }^{6}$ Asymmetry in bridged binuclear metalloenzymes has also provided lessons for the synthetic chemist in a much broader sense, and a variety of unsymmetric compartmental ligand scaffolds have been designed to study the mutual effects of the two metals., ${ }^{4,7}$ One strategy to achieve coordination site distinction is the attachment of two different chelating sidearms to an endogenenous bridging moiety such as phenolate,,${ }^{7,8}$ pyrazolate, ${ }^{9}$ or oxadiazole. ${ }^{10}$ Few known systems, however, approach an extreme situation in which an organometallic fragment and a Werner-type fragment having the same metal ion are preorganized in close proximity. ${ }^{11}$

In the case of pyrazolate-based homobimetallic complexes, the two metal ions spanned by the heterocycle are in the same oxidation state in most cases. ${ }^{12,13}$ It should be noted though that the pyrazolate bridge provides significant electronic coupling, and mutual metal oxidative deactivation upon oxidative addition to one of the two metals as well as fast electron transfer in mixed-valence species has been reported. ${ }^{14,15} \mathrm{We}$ studied in detail the dimanganese complex $\mathbf{1}^{-}$, which was shown to undergo two sequential one-electron metal-centered oxidations with fast intramolecular thermal electron transfer $\left(k_{\mathrm{ET}} \approx 2.6 \times 10^{10} \mathrm{~s}^{-1}\right.$ at $\left.298 \mathrm{~K}\right)$ in the mixed-valent $\mathrm{Mn}^{\mathrm{I}} \mathrm{Mn}^{\mathrm{II}}$ species, having a formal low-spin $\mathrm{d}^{5} \mathrm{~d}^{6}$ electronic configuration. ${ }^{15}$ In a further elaboration, the multifunctional system $\mathrm{HL}^{\mathrm{Mn}}$, with both a $\mathrm{CpMn}(\mathrm{CO})_{2}$ subunit and a $\left\{\mathrm{N}_{4}\right\}$ donor compartment tethered to the central pyrazole, has been developed. Redox-inactive zinc(II) ions with different coligands $(\mathrm{X})$ can be accommodated in the Werner-type compartment (e.g., in $\left.\mathrm{L}^{\mathrm{Mn}} \mathrm{ZnCl}\right){ }^{11}{ }^{116}$ Variations in the zinc site were shown to induce subtle changes in the redox properties of the organometallic site. ${ }^{16}$ These highly unsymmetric heterobinuclear compounds, $\mathbf{A}$, can be formally

(5) (a) Stenkamp, R. E. Chem. Rev. 1994, 94, 715-726 and references therein. (b) Shiemke, A. K.; Loehr, T. M.; Sanders-Loehr, J. J. Am. Chem. Soc. 1986, 108, 2437-2443.

(6) (a) Bosnich, R. Inorg. Chem. 1999, 38, 2554-2562. (b) Qin, C. J.; Gavrilova, A.; Bosnich, B. Pure Appl. Chem. 2001, 73, 221-226.

(7) (a) Fenton, D. E.; Okawa, H. Chem. Ber./Recl. 1997, 130, 433-442. (b) Fenton, D. E. Inorg. Chem. Commun. 2002, 5, 537-547.

(8) Incarvito, C.; Rheingold, A. L.; Gavrilova, A. L.; Qin, C. J.; Bosnich, B. Inorg. Chem. 2001, 40, 1386-1390.

(9) (a) Konrad, M.; Meyer, F.; Heinze, K.; Zsolnai, L. J. Chem. Soc. Dalton Trans. 1998, 199-205. (b) Konrad, M.; Wuthe, S.; Meyer, F.; Kaifer, E. Eur. J. Inorg. Chem. 2001, 2233-2240.

(10) Gavrilova, A. L.; Qin, C. J.; Sommer, R. D.; Rheingold, A. L.; Bosnich, B. J. Am. Chem. Soc. 2002, 124, 1714-1722.

(11) Röder, J. C.; Meyer, F.; Kaifer, E. J. Organomet. Chem. 2002, 641, $113-120$.

(12) (a) Trofimenko, S. Prog. Inorg. Chem. 1986, 34, 115-210. (b) La Monica, G.; Ardizzoia, G. A. Prog. Inorg. Chem. 1997, 46, 151238. (c) Mukherjee, R. Coord. Chem. Rev. 2000, 203, 151-218.

(13) Tejel, C.; Ciriano, M. A.; López, J. A.; Lahoz, F. J.; Oro, L. A. Angew. Chem. 1998, 110, 1647-1650.

(14) Schenck, T. G.; Milne, C. R. C.; Sawyer, J. F.; Bosnich, B. Inorg. Chem. 1985, 24, 2338-2344.

(15) (a) Röder, J. C.; Meyer, F.; Kaifer, E. Angew. Chem. 2002, 114, $2414-$ 2417; Angew. Chem., Int. Ed. 2002, 41, 2304-2306. (b) Röder, J. C.; Meyer, F.; Hyla-Kryspin, I.; Winter, R. F.; Kaifer, E. Chem.-Eur. J. 2003, 9, 2636-2648.

(16) Sheng, T.; Dechert, S.; Stückl, A. C.; Meyer, F. Eur. J. Inorg. Chem. 2005, 1293-1302.
Scheme 1. Synthesis of Dimanganese(I,II) Complexes

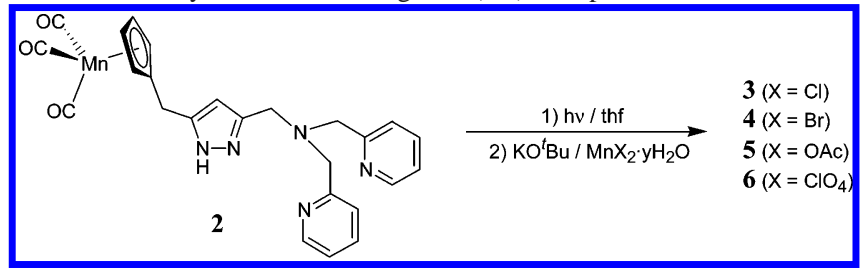

described as a combination of one type $\mathbf{B}$ subunit and one type $\mathbf{C}$ subunit, that is, as an assembly of both a Wernertype entity (C-type) and an organometallic entity (B-type) in a highly preorganized bimetallic array.

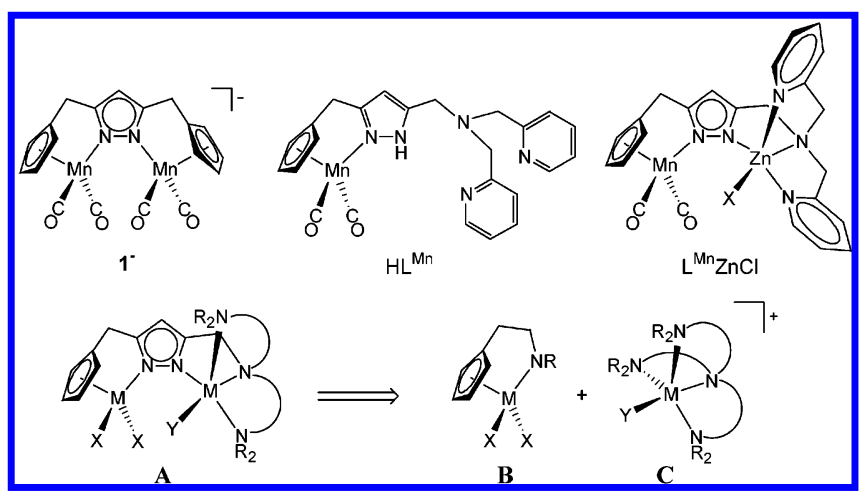

In this work we have now investigated a novel series of type A homobimetallic dimanganese complexes based on $\mathrm{HL}^{\mathrm{Mn}}$ that accommodate a second manganese ion in the Werner-type (C-type) site. It was anticipated that the pronounced asymmetry of the ligand environment in $\mathbf{A}$ would ensure site control of the one-electron redox processes. In particular, the mixed-valent species could be expected to exhibit strict site confinement and localized valency despite the short metal-metal distance and despite the efficient electronic coupling provided by the pyrazolate. The electronic structure of these unusual homobimetallic systems is probed by various spectroscopic methods and by extensive density functional theory (DFT) calculations.

\section{Results and Discussion}

Synthesis and Structural Characterization. Dimanganese complexes of type $\mathrm{L}^{\mathrm{Mn}} \mathrm{MnX}$ with a manganese(II) ion in the classical tpma-like $\{\mathrm{N} 4\}$ coordination site of $\mathrm{HL}^{\mathrm{Mn}}$ are best prepared in a one-pot synthesis starting from the precursor to $\mathrm{HL}^{\mathrm{Mn}}$, compound 2 with a dangling $\mathrm{CpMn}(\mathrm{CO})_{3}$ unit, in close analogy to the procedure reported for the heterobimetallic $\mathrm{L}^{\mathrm{Mn}} \mathrm{ZnX}$ compounds (Scheme 1). ${ }^{11,16} \mathrm{Ir}$ radiation of 2 leads to elimination of one $\mathrm{CO}$ and to intramolecular N-coordination of the pyrazolate heterocycle, and subsequent deprotonation and treatment with the respective manganese(II) salt affords the highly unsymmetric, homobimetallic complexes $\mathbf{3 - 6}$. The reaction sequence is easily followed by IR spectroscopy because the resulting complexes feature two intense bands at approximately 1905 and $1830 \mathrm{~cm}^{-1}$, that is, at significantly lower wavenumbers than those of the $\mathrm{CpMn}(\mathrm{CO})_{3}$ unit in 2 (Table 1). All four complexes could be obtained in crystalline form from dimethylformamide (DMF)/diethyl ether $\left(\mathbf{3 , 4 , 6}\right.$ ) or $\mathrm{CH}_{2} \mathrm{Cl}_{2} /$ 
Table 1. IR Absorptions in the CO Stretching Range ${ }^{a}$

\begin{tabular}{lrl}
\hline & DMF solution & \multicolumn{1}{c}{ KBr pellets } \\
\hline $\mathbf{3}$ & 1908,1834 & 1909,1836 \\
$\mathbf{3}^{+}$ & 2029,1952 & \\
$\mathbf{4}$ & 1906,1831 & 1909,1820 \\
$\mathbf{4}^{+}$ & 2029,1950 & 1907,1832 \\
$\mathbf{5}$ & 1908,1834 & \\
$\mathbf{5}^{+}$ & 2029,1951 & $1903,1893,1833,1820$ \\
$\mathbf{6}^{+}$ & 1906,1832 & \\
$\mathbf{6}^{+}$ & 2027,1950 & \\
${ }^{2}$ Values in $\mathrm{cm}^{-1}$.
\end{tabular}

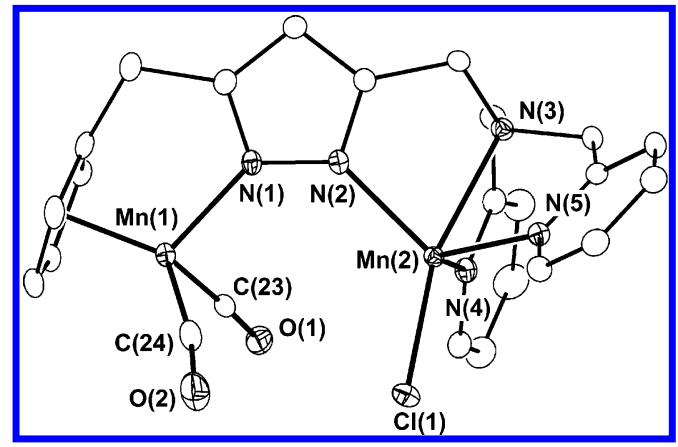

Figure 1. ORTEP plot ( $30 \%$ probability thermal ellipsoids) of the molecular structure of $\mathbf{3}$. For clarity, all hydrogen atoms have been omitted. Selected atom distances $(\AA)$ and angles $\left({ }^{\circ}\right)[\mathrm{Cg}(1)$ defines the centroid of the $\mathrm{Cp}$ ring atoms $\mathrm{C}(5)-\mathrm{C}(9)]$ : $\mathrm{Mn}(1)-\mathrm{Cg}(1)$ 1.765(1), $\mathrm{Mn}(1)-\mathrm{N}(1) 2.025-$ (2), $\mathrm{Mn}(1)-\mathrm{C}(23) 1.768(2), \mathrm{Mn}(1)-\mathrm{C}(24) 1.779(2), \mathrm{Mn}(2)-\mathrm{Cl}(1) 2.3224-$ (6), $\mathrm{Mn}(2)-\mathrm{N}(2)$ 2.116(2), $\mathrm{Mn}(2)-\mathrm{N}(3)$ 2.343(2), $\mathrm{Mn}(2)-\mathrm{N}(4) 2.197(2)$, $\mathrm{Mn}(2)-\mathrm{N}(5)$ 2.254(2), $\mathrm{Mn}(1) \cdots \mathrm{Mn}(2)$ 4.2175(4), O(1)-C(23) 1.169(3), $\mathrm{O}(2)-\mathrm{C}(24)$ 1.164(3); $\mathrm{Cg}(1)-\mathrm{Mn}(1)-\mathrm{N}(1)$ 112.3(3), $\mathrm{Cg}(1)-\mathrm{Mn}(1)-\mathrm{C}(23)$ 126.03(8), $\mathrm{Cg}(1)-\mathrm{Mn}(1)-\mathrm{C}(24)$ 121.24(9), C(23)- Mn(1)-C(24) 92.8(1), $\mathrm{C}(23)-\mathrm{Mn}(1)-\mathrm{N}(1)$ 96.99(8), C(24)- $\mathrm{Mn}(1)-\mathrm{N}(1)$ 102.73(9), O(1)$\mathrm{C}(23)-\mathrm{Mn}(1)$ 175.9(2), O(2)-C(24)-Mn(1) 170.4(2), N(2)-Mn(2)-N(4) 107.53(6), N(2)-Mn(2)-N(3) 75.04(6), N(2)-Mn(2)-N(5) 110.98(6), $\mathrm{N}(3)-\mathrm{Mn}(2)-\mathrm{N}(4) 74.83(6), \mathrm{N}(3)-\mathrm{Mn}(2)-\mathrm{N}(5)$ 72.43(6), N(4) $-\mathrm{Mn}(2)-$ $\mathrm{N}(5) 119.55(6), \mathrm{N}(2)-\mathrm{Mn}(2)-\mathrm{Cl}(1) 120.08(5), \mathrm{N}(3)-\mathrm{Mn}(2)-\mathrm{Cl}(1) 163.59-$ (5), $\mathrm{N}(4)-\mathrm{Mn}(2)-\mathrm{Cl}(1)$ 104.09(5), N(5)- $\mathrm{Mn}(2)-\mathrm{Cl}(1)$ 94.79(5).

diethyl ether (5), and their structures were elucidated by $\mathrm{X}$-ray crystallography. Their molecular structures are depicted in Figures 1-4, along with selected atom distances and bond angles.

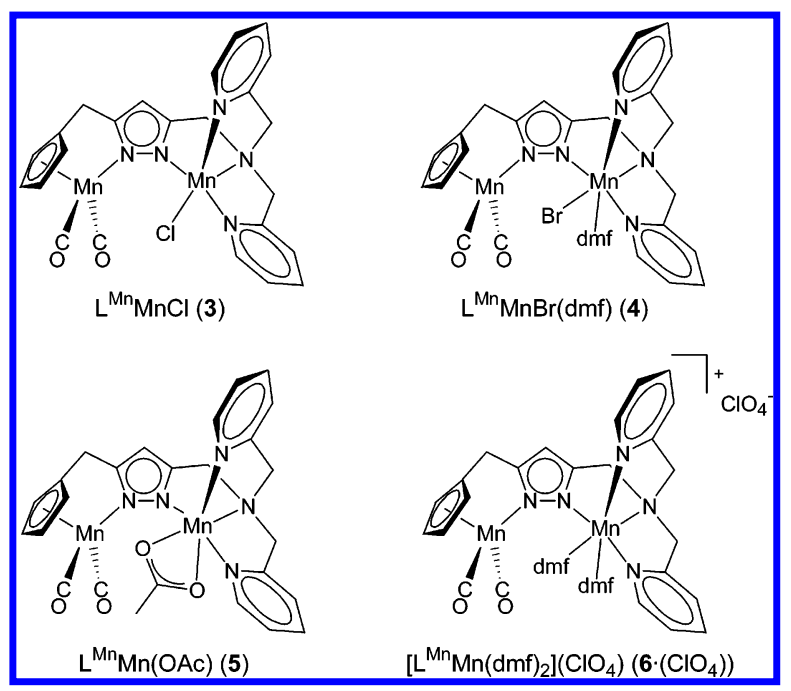

In all cases, the second manganese is nested within the $\left\{\mathrm{N}_{4}\right\}$ donor compartment, and the pyrazolate spans the two metal ions. Mn1 $\cdots \mathrm{Mn} 2$ distances are all in the range of

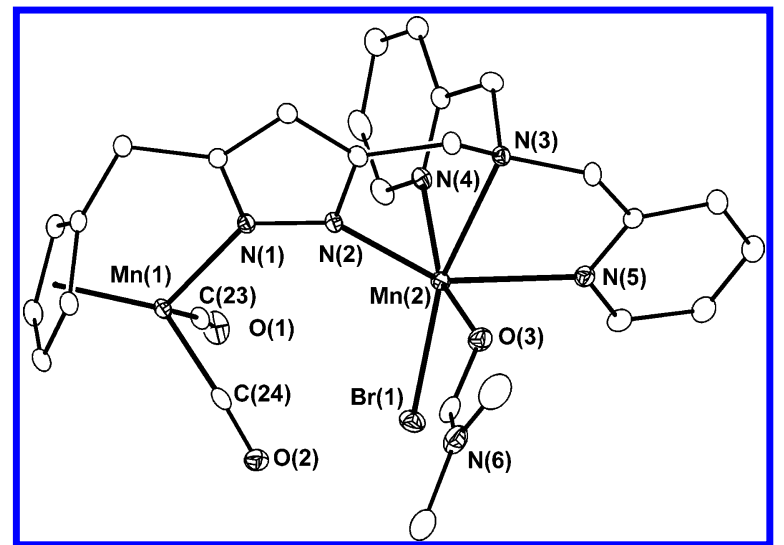

Figure 2. ORTEP plot (30\% probability thermal ellipsoids) of the molecular structure of $\mathbf{4}$. For clarity, all hydrogen atoms have been omitted. Selected atom distances $(\AA)$ and angles $\left(^{\circ}\right)[\mathrm{Cg}(1)$ defines the centroid of the $\mathrm{Cp}$ ring atoms $\mathrm{C}(5)-\mathrm{C}(9)]$ : $\mathrm{Mn}(1)-\mathrm{Cg}(1) 1.769(1), \mathrm{Mn}(1)-\mathrm{N}(1) 2.009$ (2), $\mathrm{Mn}(1)-\mathrm{C}(23)$ 1.775(2), $\mathrm{Mn}(1)-\mathrm{C}(24) 1.762(2), \mathrm{Mn}(2)-\mathrm{Br}(1) 2.5535-$ (4), $\mathrm{Mn}(2)-\mathrm{N}(2)$ 2.224(2), $\mathrm{Mn}(2)-\mathrm{N}(3)$ 2.374(2), $\mathrm{Mn}(2)-\mathrm{N}(4)$ 2.268(2), $\mathrm{Mn}(2)-\mathrm{N}(5)$ 2.332(2), $\mathrm{Mn}(2)-\mathrm{O}(3)$ 2.232(2), $\mathrm{Mn}(1) \cdots \mathrm{Mn}(2)$ 4.3813(5), $\mathrm{O}(1)-\mathrm{C}(23) 1.165(3), \mathrm{O}(2)-\mathrm{C}(24) 1.172(3) ; \mathrm{Cg}(1)-\mathrm{Mn}(1)-\mathrm{N}(1) 112.69-$ (6), $\mathrm{Cg}(1)-\mathrm{Mn}(1)-\mathrm{C}(23)$ 123.51(8), $\mathrm{Cg}(1)-\mathrm{Mn}(1)-\mathrm{C}(24)$ 126.04(8), $\mathrm{C}(23)-\mathrm{Mn}(1)-\mathrm{C}(24) 92.8(1), \mathrm{C}(23)-\mathrm{Mn}(1)-\mathrm{N}(1) 101.05(8), \mathrm{C}(24)-\mathrm{Mn}-$ (1) $\mathrm{N}(1)$ 94.80(8), O(1)-C(23)-Mn(1) 172.6(2), O(2)-C(24)-Mn(1) 176.5(2), N(2)-Mn(2)-N(3) 75.76(6), N(2)-Mn(2)-N(4) 87.98(6), N(2)$\mathrm{Mn}(2)-\mathrm{N}(5)$ 147.77(6), N(3)-Mn(2)-N(4) 75.12(6), N(3)-Mn(2)-N(5) 72.05(6), $\mathrm{N}(4)-\mathrm{Mn}(2)-\mathrm{N}(5)$ 85.47(6), $\mathrm{N}(2)-\mathrm{Mn}(2)-\mathrm{O}(3)$ 86.17(6), $\mathrm{N}(3)-$ $\mathrm{Mn}(2)-\mathrm{O}(3)$ 83.13(6), N(4) $-\mathrm{Mn}(2)-\mathrm{O}(3)$ 158.24(6), N(5)- $\mathrm{Mn}(2)-\mathrm{O}(3)$ 88.36(6), $\mathrm{N}(2)-\mathrm{Mn}(2)-\mathrm{Br}(1)$ 118.26(4), N(3)- $\mathrm{Mn}(2)-\mathrm{Br}(1)$ 165.97(4), $\mathrm{N}(4)-\mathrm{Mn}(2)-\mathrm{Br}(1)$ 104.40(5), N(5)- $\mathrm{Mn}(2)-\mathrm{Br}(1)$ 93.92(4), O(3)-Mn(2) $-\operatorname{Br}(1) 96.81(4)$

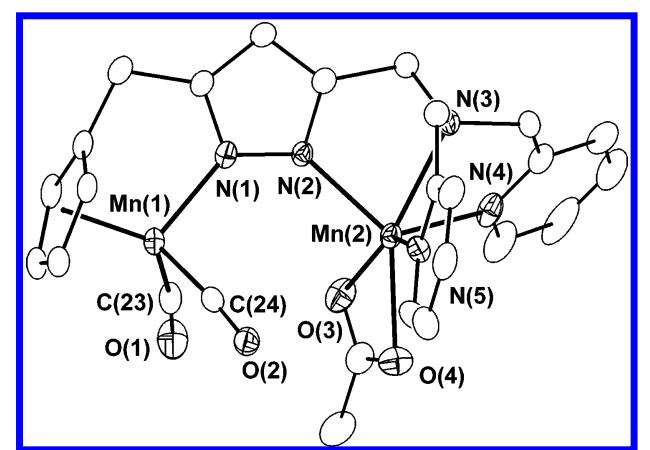

Figure 3. ORTEP plot (30\% probability thermal ellipsoids) of the molecular structure of $\mathbf{5}$. For clarity, all hydrogen atoms have been omitted. Selected atom distances $(\AA)$ and angles $\left(^{\circ}\right)[\mathrm{Cg}(1)$ defines the centroid of the $\mathrm{Cp}$ ring atoms $\mathrm{C}(5)-\mathrm{C}(9)]$ : $\mathrm{Mn}(1)-\mathrm{Cg}(1)$ 1.768(3), $\mathrm{Mn}(1)-\mathrm{C}(23)$ 1.773(6), Mn(1)-C(24) 1.766(6), Mn(1)-N(1) 2.024(4), Mn(2)-N(2) 2.153(4), $\mathrm{Mn}(2)-\mathrm{N}(3)$ 2.376(5), $\mathrm{Mn}(2)-\mathrm{N}(4) 2.264(5), \mathrm{Mn}(2)-\mathrm{N}(5)$ 2.223(4), $\mathrm{Mn}(2)-\mathrm{O}$ (3) 2.241(5), $\mathrm{Mn}(2)-\mathrm{O}$ (4) 2.236(4), $\mathrm{Mn}(1) \cdots \mathrm{Mn}(2) 4.257-$ (1), $\mathrm{O}(1)-\mathrm{C}(23) 1.165(7), \mathrm{O}(2)-\mathrm{C}(24)$ 1.168(7); $\mathrm{Cg}(1)-\mathrm{Mn}(1)-\mathrm{N}(1)$ 111.6(2), $\mathrm{Cg}(1)-\mathrm{Mn}(1)-\mathrm{C}(23)$ 122.4(2), $\mathrm{Cg}(1)-\mathrm{Mn}(1)-\mathrm{C}(24)$ 125.5(2), $\mathrm{C}(23)-\mathrm{Mn}(1)-\mathrm{C}(24)$ 91.4(3), C(23)-Mn(1)-N(1) 102.6(2), C(24)-Mn(1) $-\mathrm{N}(1)$ 98.7(2), $\mathrm{O}(1)-\mathrm{C}(23)-\mathrm{Mn}(1)$ 171.7(5), O(2)-C(24)-Mn(1) 174.9(5), N(2)-Mn(2)-N(3) 74.1(2), N(2)-Mn(2)-N(4) 117.8(2), N(2)$\mathrm{Mn}(2)-\mathrm{N}(5) \quad 100.3(2), \mathrm{N}(3)-\mathrm{Mn}(2)-\mathrm{N}(4) 70.8(2), \mathrm{N}(3)-\mathrm{Mn}(2)-\mathrm{N}(5)$ 72.7(2), N(4) $-\mathrm{Mn}(2)-\mathrm{N}(5)$ 115.4(2), O(3) $-\mathrm{Mn}(2)-\mathrm{N}(2)$ 94.1(2), O(3)$\mathrm{Mn}(2)-\mathrm{N}(3)$ 144.2(2), O(3) $-\mathrm{Mn}(2)-\mathrm{N}(4)$ 86.4(2), O(3)-Mn(2)-N(5) 143.1(2), O(4)-Mn(2)- $\mathrm{N}(2)$ 134.9(2), O(4) $-\mathrm{Mn}(2)-\mathrm{N}(3)$ 148.7(2), O(4)$\mathrm{Mn}(2)-\mathrm{N}(4)$ 97.2(2), O(4)-Mn(2)-N(5) 88.0(2), O(3)-Mn(2)-O(4) 58.7(2).

4.212-4.381 $\AA$. Although the Mn2 ion is six-coordinate in 4-6, it remains five-coordinate with a distorted trigonalbipyramidal geometry $(\tau=0.73)^{17}$ in the chloro complex 3 . Steric hindrance between the $\mathrm{Cl}$ atom and the $\mathrm{Mn}$-bound $\mathrm{CO}$ ligands presumably causes deviation from a linear N3Mn2-Cl1 arrangement and prohibits the coordination of an 
Sheng et al.

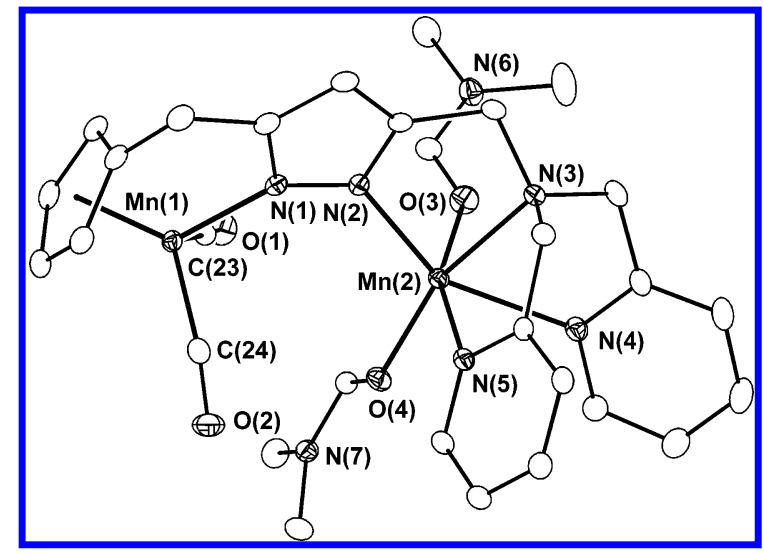

Figure 4. ORTEP plot ( $30 \%$ probability thermal ellipsoids) of the molecular structure of $\mathbf{6}$. For clarity, all hydrogen atoms and the second crystallographically independent molecule have been omitted. $[\mathrm{Cg}(1)$ defines the centroid of the $\mathrm{Cp}$ ring atoms $\mathrm{C}(5)-\mathrm{C}(9) / \mathrm{C}(105)-\mathrm{C}(109)]$ : $\mathrm{Mn}(1)-$ $\mathrm{Cg}(1)$ 1.762(1)/1.762(1), $\mathrm{Mn}(1)-\mathrm{N}(1) 2.016(2) / 2.015(2), \mathrm{Mn}(1)-\mathrm{C}(23)$ $1.762(3) / 1.764(2), \mathrm{Mn}(1)-\mathrm{C}(24) 1.775(2) / 1.767(2), \mathrm{Mn}(2)-\mathrm{N}(2) 2.170-$ (2)/2.146(2), $\mathrm{Mn}(2)-\mathrm{N}(3)$ 2.372(2)/2.365(2), $\mathrm{Mn}(2)-\mathrm{N}(4) 2.332(2) / 2.292$ (2), $\mathrm{Mn}(2)-\mathrm{N}(5) 2.269(2) / 2.288(2), \mathrm{Mn}(2)-\mathrm{O}(3) 2.154(2) / 2.256(2), \mathrm{Mn}-$ (2) $-\mathrm{O}(4) 2.103(2) / 2.112(2), \mathrm{Mn}(1) \cdots \mathrm{Mn}(2) 4.2550(5) / 4.2121(5), \mathrm{O}(1)-$ $\mathrm{C}(23) 1.167(3) / 1.174(3), \mathrm{O}(2)-\mathrm{C}(24) 1.169(3) / 1.170(3) ; \mathrm{Cg}(1)-\mathrm{Mn}(1)-$ $\mathrm{N}(1) 111.75(7) / 111.74(7), \mathrm{Cg}(1)-\mathrm{Mn}(1)-\mathrm{C}(23)$ 124.53(9)/123.61(9), $\mathrm{Cg}(1)-$ $\mathrm{Mn}(1)-\mathrm{C}(24)$ 123.85(9)/123.10(8), C(23)-Mn(1)-C(24) 92.8(1)/93.1(1), $\mathrm{C}(23)-\mathrm{Mn}(1)-\mathrm{N}(1) \quad 96.88(9) / 99.47(9), \mathrm{C}(24)-\mathrm{Mn}(1)-\mathrm{N}(1) \quad 101.87(9) /$ 101.29(9), O(1)-C(23)- Mn(1) 175.4(2)/173.8(2), O(2)-C(24)-Mn(1) $173.6(2) / 172.6(2), \mathrm{N}(2)-\mathrm{Mn}(2)-\mathrm{N}(3)$ 75.04(7)/75.52(7), N(2)-Mn(2)$\mathrm{N}(4) 147.52(7) / 145.85(7), \mathrm{N}(2)-\mathrm{Mn}(2)-\mathrm{N}(5)$ 96.04(7)/99.70(7), N(3)$\mathrm{Mn}(2)-\mathrm{N}(4) \quad 72.55(6) / 73.06(7), \mathrm{N}(3)-\mathrm{Mn}(2)-\mathrm{N}(5) \quad 75.85(6) / 75.84(6)$, $\mathrm{N}(4)-\mathrm{Mn}(2)-\mathrm{N}(5)$ 78.18(7)/85.35(7), O(3) $-\mathrm{Mn}(2)-\mathrm{N}(2)$ 94.91(7)/91.33(7), $\mathrm{O}(3)-\mathrm{Mn}(2)-\mathrm{N}(3) 90.12(7) / 102.58(6), \mathrm{O}(3)-\mathrm{Mn}(2)-\mathrm{N}(4) 83.14(7) /$ 82.81(7), O(3)- Mn(2)-N(5) 159.28(7)/167.97(7), O(4)-Mn(2)-N(2) 118.38(7)/120.80(7), O(4) $-\mathrm{Mn}(2)-\mathrm{N}(3) 164.10(7) / 160.45(6), \mathrm{O}(4)-\mathrm{Mn}(2)-\mathrm{N}(4)$ 93.98(7)/92.76(7), O(4)-Mn(2)-N(5) 93.42(6)/89.93(6), O(3)-Mn(2)$\mathrm{O}(4)$ 96.77(7)/88.53(6).

additional ligand. In contrast, the much longer $\mathrm{Mn} 2-\mathrm{Br}$ bond in 4 leaves sufficient space at the metal ion to accommodate an additional DMF solvent molecule, leading to a strongly distorted octahedral environment. The perchlorate anions in 6 are noncoordinating, and hence two DMF molecules complete the $\mathrm{Mn} 2$ coordination sphere. The acetate ligand in $\mathbf{5}$ is acting as a chelate with two almost identical $\mathrm{Mn}-\mathrm{O}$ bonds $[d(\mathrm{Mn} 2-\mathrm{O})=2.241(5) / 2.236(4) \AA]$. As expected, bonds between the low-spin $\mathrm{d}^{6} \mathrm{Mn} 1$ ion and the pyrazolateN1 are significantly shorter than those between the highspin $\mathrm{d}^{5} \mathrm{Mn} 2$ ion and the pyrazolate $-\mathrm{N} 2[2.009(2)-2.025(2)$ versus 2.116(2)-2.224(2) $\AA$, respectively].

A certain flexibility of the dimanganese framework is reflected by the different torsion angles $\mathrm{Mn} 1-\mathrm{N} 1-\mathrm{N} 2-\mathrm{Mn} 2$ adopted in $\mathbf{3}-\mathbf{6}$, which range from 0.9 to $35.0^{\circ}$. This allows the systems to cope with the different steric pressure within the bimetallic pocket that arises from the steric crowding of the Mn1-bound $\mathrm{CO}$ and the various coligands bound to Mn2. In particular, two independent molecules per unit cell are found in the crystal structure of $\mathbf{6}$. Although constitutionally identical, these molecules show different mutual orientations

(17) The angular structural parameter $\tau=(\beta-\alpha) / 60$ defines the degree of trigonality. $\alpha$ and $\beta$ represent the two largest angles around the central atom with $\beta>\alpha$. A perfect trigonal-bipyramidal structure is thus associated with $\tau=1$, whereas $\tau=0$ is expected for ideal squarepyramidal geometry. Addison, A. W.; Rao, T. N.; Reedijk, J.; van Rijn, J.; Verschoor, G. C. J. Chem. Soc., Dalton Trans. 1984, 13491356.
Table 2. Formal Potentials for the $\mathrm{Mn}^{\mathrm{I}} / \mathrm{Mn}^{\mathrm{II}}$ Couple in $\mathrm{DMF} / 0.1 \mathrm{M}$ $\mathrm{Bu}_{4} \mathrm{NPF}_{6}{ }^{19}$

\begin{tabular}{ccc}
\hline complex & $E_{1 / 2}\left(\mathrm{Mn}^{\mathrm{I}} \mathrm{Mn}^{\mathrm{II}} / \mathrm{Mn}^{\mathrm{II}} \mathrm{Mn}^{\mathrm{II}}\right)$ & $E^{p}{ }_{\text {red }}\left(\mathrm{Mn}^{\mathrm{I}} \mathrm{Mn}^{\mathrm{II}} / \mathrm{Mn}^{\mathrm{I}} \mathrm{Mn}^{\mathrm{I}}\right)^{a}$ \\
\hline $\mathbf{3}$ & -0.63 & -2.62 \\
$\mathbf{4}$ & -0.60 & -2.52 \\
$\mathbf{5}$ & -0.63 & -2.68 \\
$\mathbf{6}$ & -0.51 & -2.52
\end{tabular}

${ }^{a}$ Peak potentials for irreversible reduction process at $100 \mathrm{mV} / \mathrm{s}$.

of the DMF ligands, which are accompanied by a drastic difference in the $\mathrm{Mn}-\mathrm{N}-\mathrm{N}-\mathrm{Mn}$ torsion angle (4.2 versus $35.0^{\circ}$ ). The presence of two distinct species in the crystalline state is also evident from the $v_{\mathrm{CO}}$ region of the IR spectrum (see below). Nevertheless, in all complexes 3-6, the $\pi$ plane of the bridging pyrazolate roughly coincides with the mirror plane of the $\operatorname{Mn}^{\mathrm{I}}(\mathrm{CO})_{2}$ fragments, which is a favorable situation for stabilizing electronic $\pi$-interactions. ${ }^{18}$ Because these compounds represent rare examples of neutral $\mathrm{d}^{5} \mathrm{~d}^{6}$ mixed-valent complexes and feature a unique asymmetry of the binuclear framework, a detailed investigation by cyclic voltammetry and UV/vis and IR spectroelectrochemistry was performed.

Discussion of Spectroscopic and Electrochemical Results. All complexes 3-6 show two strong IR bands of similar relative intensities in the $\mathrm{C} \equiv \mathrm{O}$ stretching region, with $\boldsymbol{v}_{\mathrm{s}}(\mathrm{CO})$ (symmetric) and $\boldsymbol{v}_{\mathrm{as}}(\mathrm{CO})$ (asymmetric) of the (Mn$\left.(\mathrm{CO})_{2}\right\}$ fragment at approximately 1907 and $1832 \mathrm{~cm}^{-1}$, respectively (Table 1). The presence of two independent molecules in the crystal structure of $\mathbf{6}$ is reflected by the occurrence of two slightly different pairs of $\boldsymbol{v}(\mathrm{C} \equiv \mathrm{O})$ stretches. IR spectra of solid $\mathbf{4}$ and $\mathbf{6}$ clearly show the presence of the bound DMF with $\boldsymbol{v}(\mathrm{C}=\mathrm{O})$ stretching at 1653 and $1659 \mathrm{~cm}^{-1}$, respectively. The presence of various bands in the region below $1605 \mathrm{~cm}^{-1}$ for all complexes prevents us from unambiguously assigning one specific band as the $\boldsymbol{v}(\mathrm{COO})$ absorption of the acetate ligand in $\mathbf{5}$.

Cyclic voltammograms of complexes 3-5 in DMF solution feature a reversible redox wave at approximately $E_{1 / 2}$ $=-0.63 \mathrm{~V}$ (Table 2), ${ }^{19}$ which we assign to the formation of the $\mathrm{Mn}^{\mathrm{II}} \mathrm{Mn}^{\mathrm{II}}\left(\mathrm{d}^{5} \mathrm{~d}^{5}\right)$ species. The cyclic voltammogram of 5 is depicted in Figure 5 as an example. The oxidation wave of the cationic complex $\mathbf{6}$ is somewhat shifted anodically $(-0.51 \mathrm{~V})$ with respect to the neutral congeners, and this indicates that the absence of anionic (electron donating) coligands at the Werner-type manganese(II) site renders oxidation of the organometallic site more difficult. Compared to the analogous $\mathrm{L}^{\mathrm{Mn}} \mathrm{ZnX}$ complexes, changes at the coordination sphere of the manganese(II) ion in 3-6 exert a slightly more pronounced influence on the redox potential. Reduction of all complexes $\mathbf{3 - 6}$ is an irreversible process and occurs only at very low potential, approximately -2.6 $\mathrm{V}$ versus ferrocene. The huge separation of the two electro-

(18) (a) Caulton, K. G.; Coord. Chem. Rev. 1981, 38, 1-43. (b) Kaim, W.; Gross, R. Comments Inorg. Chem. 1988, 7, 269-285.

(19) Values versus the ferrocene/ferrocenium couple: $i_{\mathrm{p} a} / i_{\mathrm{pc}}$ close to $1 ; i_{\mathrm{pd}}$ $\mathrm{v}^{1 / 2} \approx$ const; $\Delta E_{\mathrm{p}}=E_{\mathrm{p}}{ }^{\text {ox }}-E_{\mathrm{p}}{ }^{\text {red }}=70 \mathrm{mV}(\mathbf{3}), 110 \mathrm{mV}(\mathbf{4}), 105 \mathrm{mV}$ (5), or $87 \mathrm{mV}(\mathbf{6})$, with $\Delta E_{\mathrm{p}}\left(\mathrm{Cp}_{2} \mathrm{Fe} / \mathrm{Cp}_{2} \mathrm{Fe}^{+}\right)=85 \mathrm{mV}(\mathbf{3}), 104 \mathrm{mV}$ (4), $113 \mathrm{mV}$ (5), or $102 \mathrm{mV}$ (6) under the same experimental conditions. 


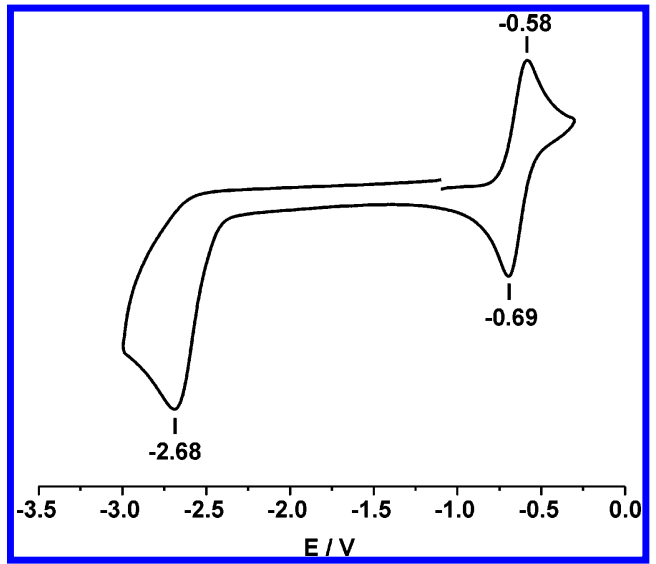

Figure 5. Cyclic voltammogram of $\mathbf{5}$ recorded on a platinum electrode in DMF containing $\sim 0.1 \mathrm{M} \mathrm{N}^{\mathrm{n} B \mathrm{Bu}_{4}}{ }^{+} \mathrm{PF}_{6}{ }^{-}$; scan speed $100 \mathrm{mVs}^{-1}$; potentials are given in volts versus the $\mathrm{Fc} / \mathrm{Fc}^{+}$couple.

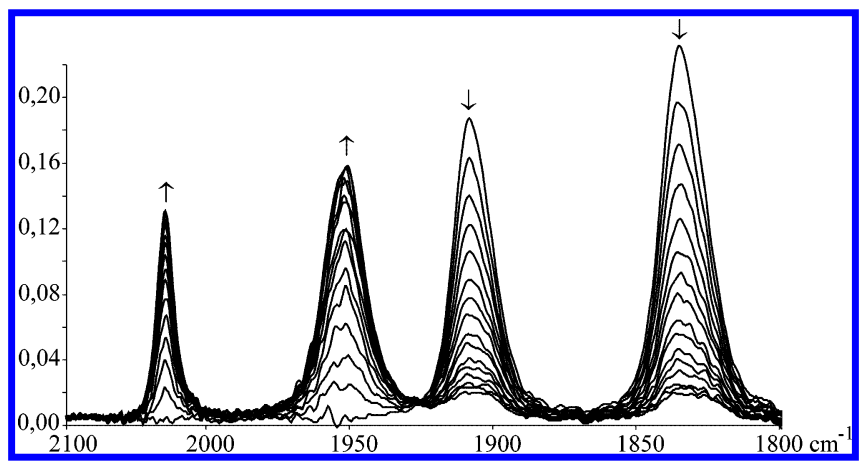

Figure 6. IR spectroscopic changes during the gradual oxidation of $\mathbf{3} \rightarrow$ $3^{+}$in DMF solution in an OTTLE cell.

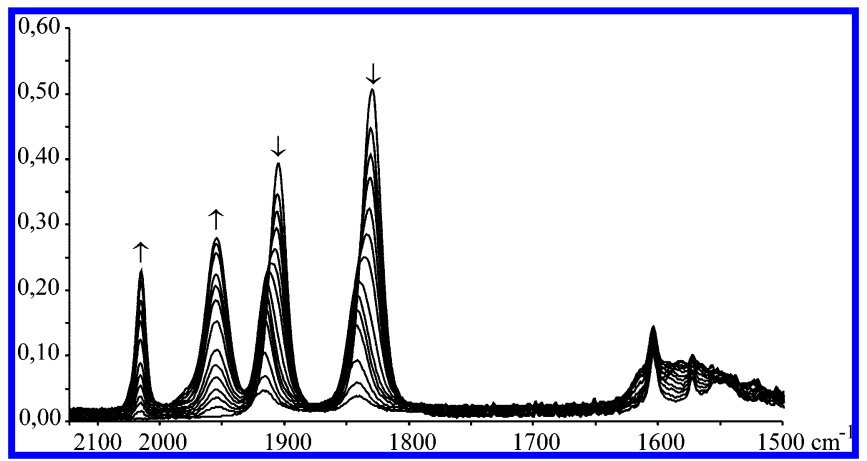

Figure 7. IR spectroscopic changes during the gradual oxidation of $\mathbf{5} \rightarrow$ $\mathbf{5}^{+}$in dichloroethane solution in an OTTLE cell.

chemical processes reveals that the mixed-valent state is thermodynamically stable in all cases.

To further characterize the oxidized dimanganese species and to clearly establish where changes take place, the oxidation of $\mathbf{3}$ and $\mathbf{5}$ in DMF and 1,2-dichloroethane, respectively, was followed by IR and UV/vis spectroscopy in an optically transparent thin-layer electrolysis (OTTLE) cell (Figures 6 and 7). Upon gradual electrolysis of 3, the pair of CO stretching vibrations at 1835 and $1909 \mathrm{~cm}^{-1}$ decreases at the expense of two new bands at 1952 and 2030 $\mathrm{cm}^{-1}$, thus confirming the structural integrity of the CpMn$(\mathrm{CO})_{2}$ fragment upon the generation of $\mathbf{3}^{+}$. The slightly lower intensity of the new bands is as expected because in $\mathrm{Mn}-$ $\mathrm{CO}$ moieties spectral intensities usually decrease with increasing oxidation state. ${ }^{20}$ The shift to higher frequencies

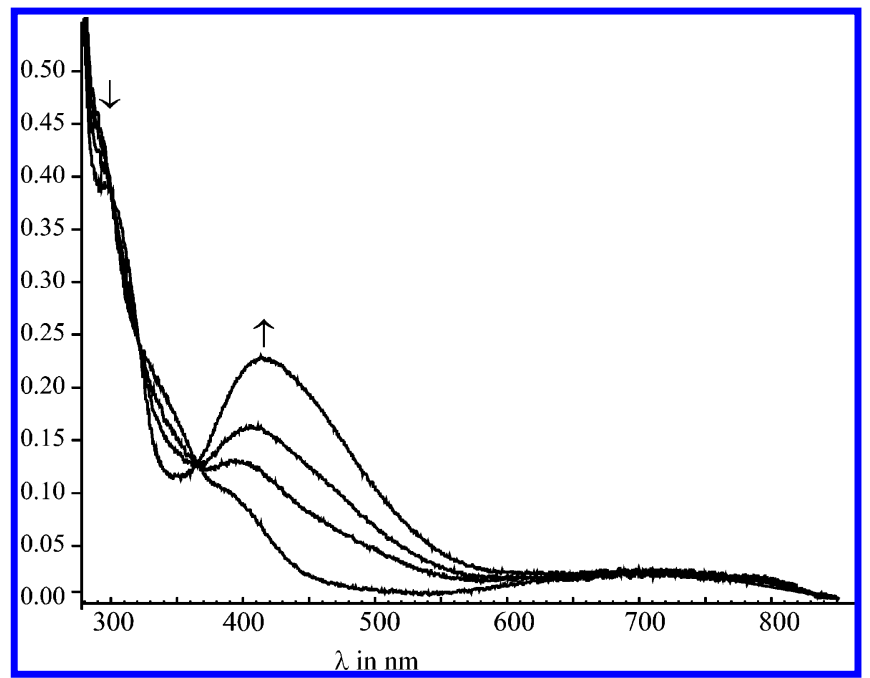

Figure 8. UV/vis spectroscopic changes during the gradual oxidation of $\mathbf{3} \rightarrow \mathbf{3}^{+}$in DMF solution in an OTTLE cell.

of $\sim 120 \mathrm{~cm}^{-1}$ is very similar to the shift observed in the corresponding $\mathrm{L}^{\mathrm{Mn}} \mathrm{ZnCl}$ complex and reflects the diminished back-bonding ability in the oxidized $\mathrm{CpMn}^{\mathrm{II}}(\mathrm{CO})_{2}$ subunit. This clearly reveals that the anodic process in $\mathbf{3}$ is centered at the organometallic site. Because carbonyl shifts are considered to track the electron densities on the metal ions, these experimental findings point to a pronounced charge localization in the mixed-valent compound $\mathbf{3}$. The presence of several isosbestic points confirms clean conversion between the $\mathrm{Mn}^{\mathrm{I}} \mathrm{Mn}^{\mathrm{II}}$ and $\mathrm{Mn}^{\mathrm{II}} \mathrm{Mn}^{\mathrm{II}}$ species. Because the original spectrum of the starting material $\mathbf{3}$ is almost restored upon rereduction, the oxidized species should be quite stable in solution. Unfortunately, attempts to crystallize any of the homovalent $\mathrm{Mn}^{\mathrm{II}} \mathrm{Mn}^{\mathrm{II}}$ complexes after chemical oxidation have hitherto failed.

A similar shift in CO stretching frequencies from 1832 and $1907 \mathrm{~cm}^{-1}$ to 1956 and $2033 \mathrm{~cm}^{-1}$, respectively, occurs upon oxidation in the case of 5 (Figure 7). No major changes are observed in the range of $1500-1700 \mathrm{~cm}^{-1}$ in which $v_{\text {as }}(\mathrm{C}=\mathrm{O})$ of the acetate ligand is to be expected, again confirming that oxidation takes place at the organometallic site. A gradual shift of $\sim 10 \mathrm{~cm}^{-1}$ to higher energy for the $v_{\mathrm{CO}}$ bands of the starting material $\mathbf{5}$ during oxidation is presumably caused by some kind of adsorption phenomenon or some precipitation. It should be noted in this respect that oxidation (and rereduction) of $\mathbf{5}$ is a very slow process, even at potentials far beyond $E_{1 / 2}$.

In UV/vis spectroelectrochemistry, the oxidation of $\mathbf{3}$ and 5 is accompanied by an increase in absorptivity (Figure 8 and Supporting Information Figure S1) due to the appearance of new bands at 411 and $402 \mathrm{~nm}$, respectively. Again, the rise of a similar band at $\sim 400 \mathrm{~nm}$ has also been observed upon oxidation of the $\mathrm{L}^{\mathrm{Mn}} \mathrm{ZnCl}$ system, and this absorption can thus be safely assigned to the $\pi$ (pyrazolate) $\rightarrow$ $\mathrm{CpMn}^{\mathrm{II}}(\mathrm{CO})_{2}$ ligand-to-metal charge transfer transition.

Theoretical Investigations. To gain deeper insight into the molecular and electronic structures of the $\mathrm{Mn}^{\mathrm{I}} \mathrm{Mn}^{\mathrm{II}}$ and

(20) (a) Bullock, J. P.; Mann, K. R. Inorg. Chem. 1989, 28, 4006-4011. (b) Pierce, D. T.; Geiger, W. E. Inorg. Chem. 1994, 33, 373-381. 
Table 3. Selected Optimized Parameters of $\mathbf{6}^{\mathbf{3}}$ and ${ }^{\mathbf{6}} \mathbf{5}$ in Comparison with the Corresponding X-ray Data ${ }^{a}$

\begin{tabular}{|c|c|c|c|c|c|c|}
\hline & \multicolumn{3}{|c|}{63} & \multicolumn{3}{|c|}{65} \\
\hline & $\exp$ & B3LYP/6-311G* & BP86/6-311G* & $\exp$ & B3LYP/6-311G* & BP86/6-311G* \\
\hline $\mathrm{Mn} 1-\mathrm{N} 1$ & 2.025 & $2.020(2.004)$ & $1.980(1.968)$ & 2.024 & $2.045(2.030)$ & $2.012(2.001)$ \\
\hline $\mathrm{Mn} 2-\mathrm{N} 2$ & 2.116 & $2.104(2.095)$ & $2.072(2.063)$ & 2.153 & $2.140(2.136)$ & $2.116(2.108)$ \\
\hline $\mathrm{Mn} 2-\mathrm{Cl} / \mathrm{Mn} 2-\mathrm{O}_{\mathrm{OAc}}{ }^{b}$ & 2.322 & $2.343(2.417)$ & $2.322(2.400)$ & 2.239 & $2.221(2.276)$ & $2.218(2.275)$ \\
\hline $\mathrm{Mn} 2-\mathrm{N} 4 / \mathrm{N} 5^{b}$ & 2.223 & $2.279(2.236)$ & $2.244(2.201)$ & 2.244 & $2.344(2.297)$ & $2.307(2.264)$ \\
\hline $\mathrm{Mn} 1-\mathrm{C}_{\mathrm{C} \equiv \mathrm{O}(1)}$ & 1.768 & $1.776(1.763)$ & $1.766(1.754)$ & 1.766 & $1.774(1.763)$ & $1.762(1.751)$ \\
\hline $\mathrm{Mn} 1-\mathrm{C}_{\mathrm{C}} \equiv \mathrm{O}(2)$ & 1.779 & $1.786(1.774)$ & $1.772(1.760)$ & 1.773 & $1.782(1.767)$ & $1.771(1.756)$ \\
\hline $\mathrm{Mn} 1-\mathrm{C}(\mathrm{Cp})^{b}$ & 2.138 & $2.172(2.208)$ & $2.143(2.177)$ & 2.143 & $2.172(2.208)$ & $2.143(2.177)$ \\
\hline $\mathrm{C}_{\mathrm{C} \equiv \mathrm{O}}-\mathrm{O}(1)$ & 1.169 & $1.162(1.182)$ & $1.180(1.208)$ & 1.168 & $1.162(1.188)$ & $1.181(1.208)$ \\
\hline $\mathrm{C}_{\mathrm{C} \equiv \mathrm{O}}-\mathrm{O}(2)$ & 1.164 & $1.157(1.189)$ & $1.175(1.203)$ & 1.165 & $1.159(1.186)$ & $1.176(1.205)$ \\
\hline $\mathrm{N} 1-\mathrm{N} 2$ & 1.369 & $1.353(1.380)$ & $1.359(1.389)$ & 1.370 & $1.355(1.384)$ & $1.363(1.395)$ \\
\hline$\angle \mathrm{C}_{\mathrm{C} \equiv \mathrm{O}(1)}-\mathrm{Mn} 1-\mathrm{N} 1$ & 97.0 & $96.6(96.2)$ & $97.5(97.5)$ & 98.7 & $97.2(96.2)$ & 98.5(97.4) \\
\hline$\angle \mathrm{C}_{\mathrm{C} \equiv \mathrm{O}(2)}-\mathrm{Mn} 1-\mathrm{N} 1$ & 102.7 & $96.2(96.5)$ & $96.0(95.9)$ & 102.6 & $99.9(100.8)$ & $100.3(101.5)$ \\
\hline$\angle \mathrm{Mn} 1-\mathrm{N} 1-\mathrm{N} 2$ & 131.0 & 130.6(130.2) & $129.5(129.2)$ & 130.7 & $131.5(130.9)$ & $131.2(130.7)$ \\
\hline$\angle \mathrm{Mn} 2-\mathrm{N} 2-\mathrm{N} 1$ & 134.9 & $131.8(132.7)$ & $130.4(131.5)$ & 136.6 & $133.8(134.7)$ & $134.0(134.8)$ \\
\hline$\angle \mathrm{Mn} 1-\mathrm{N} 1-\mathrm{N} 2-\mathrm{Mn} 2$ & 17.8 & $4.9(6.1)$ & $7.6(8.2)$ & -0.9 & $11.4(17.5)$ & $10.3(16.6)$ \\
\hline
\end{tabular}

${ }^{a}$ Distances are given in $[\AA]$, angles in degrees. Values in parentheses refer to the $6-311 \mathrm{G}$ basis. ${ }^{b}$ Mean values.

the $\mathrm{Mn}^{\mathrm{II}} \mathrm{Mn}^{\mathrm{II}}$ species as well as to characterize the spin and charge distributions in both types of complexes, we have carried out $\mathrm{DFT}^{21}$ calculations on the neutral complexes $\mathbf{3}$ and $\mathbf{5}$ in their sextet $\left({ }^{\mathbf{6}} \mathbf{3},{ }^{\mathbf{6}} \mathbf{5}\right)$ and doublet $\left({ }^{\mathbf{2}} \mathbf{3}\right)$ electronic states as well as on the respective monocations in their septet $\left({ }^{7} \mathbf{3}^{+}\right.$, ${ }^{7} \mathbf{5}^{+}$) and quintet $\left(\mathbf{5}^{+}\right)$states. Taking into account that transition-metal compounds with open-shell electronic structures-especially mixed-valent species such as those investigated here-still pose a great challenge for the theoretical methods, for our investigations we have used both the hybrid $\mathrm{B} 3 \mathrm{LYP}^{22}$ and the pure $\mathrm{BP} 86^{23}$ functionals and the all-electron basis sets $6-311 \mathrm{G}$ and $6-311 \mathrm{G}^{*}, 24,25$ as described in Calculation Details (see Experimental Section). In Table $\mathbf{3}$ we compare the optimized structures ${ }^{\mathbf{6}} \mathbf{3}$ and ${ }^{\mathbf{6}} \mathbf{5}$ with the corresponding $\mathrm{X}$-ray data. This comparison is helpful for the discussion of the cationic species $\mathbf{3}^{+}$and $\mathbf{5}^{+}$, for which X-ray data are not available. From Table 3 it is evident that the most important structural features of the neutral complexes $\mathbf{3}$ and $\mathbf{5}$ are well-reproduced by the calculations. For both functionals, the addition of polarization functions to the basis set does not influence the optimized bond angles, but it improves the accuracy of the optimized bond distances (Table 3 ). The $\mathrm{C} \equiv \mathrm{O}$ bond distances optimized with the B3LYP functional are closer to experimental values than those optimized with the BP86 functional. It is clear that this property may influence the characteristics of the calculated IR spectra (see below). Irrespective of the calculation level, the greatest discrepancy between theory and experiment involves the optimized torsion angles $\mathrm{Mn} 1-\mathrm{N} 1-$ $\mathrm{N} 2-\mathrm{Mn} 2(\phi)$. For ${ }^{6} 3$, the optimized values $\phi\left(4.9-8.2^{\circ}\right)$ are smaller than the experimental value of complex $3\left(17.8^{\circ}\right)$, whereas for ${ }^{6} \mathbf{5}$, the angles, $\phi$, range from 10.3 to $17.5^{\circ}$ and are larger than the X-ray value of complex $\mathbf{5}\left(-0.9^{\circ}\right)$ (Table

(21) Parr, R. G.; Yang, W. Density-Functional Theory of Atoms and Molecules; Oxford University Press: New York, 1989.

(22) (a) Becke, A. D. J. Chem. Phvs. 1993, 98, 5648-5652. (b) Vosko, S H.; Wilk, L.; Nusair, M. Can. J. Phys. 1980, 58, 1200-1211. (c) Lee, C.; Yang, W.; Parr, R. G. Phvs. Rev. B. 1988, 37, 785-789.

(23) (a) Becke, A. D. Phvs. Rev. A 1988, 38, 3098-3100. (b) Perdew, J. P. Phvs. Rev. B 1986, 33, 8822-8824.

(24) Krishnan, R.; Binkley, J. S.; Seeger, R.; Pople, J. A. J. Chem. Phvs. 1980, $72,650-654$

(25) Wachters, A. J. H. J. Chem. Phys. 1970, 52, 1033-1036.
3). However, crystallographic findings for 6 (in which two independent molecules with distinctly different torsion were found in the unit cell, vide supra) revealed that the bimetallic array is rather flexible with respect to variations in $\phi$. Taking into account that the theoretical data refer to the gas phase and are not subject to crystal packing forces, we realize that this discrepancy is understandable and do not consider it relevant.

Before going to the description of the cationic species, we briefly discuss the electronic structures of the neutral complexes in the sextet state. The shapes, energies, and occupation patterns of the valence $\alpha$ and $\beta$ Kohn-Sham molecular orbitals (MOs) derived from the unrestricted B3LYP/6-311G* wave function of $\mathbf{6} 3$ are presented in Figure 9 as an example. All these MOs have predominant $\mathrm{Mn}(3 \mathrm{~d})$ character and an almost perfectly localized nature. In ${ }^{\mathbf{6}} \mathbf{3}$ the Mn1 atom possesses an effective closed-shell structure, and all five unpaired electrons have predominant $\mathrm{Mn} 2(3 \mathrm{~d})$ character. The low energy of those Mn2(3d) levels suggests that the removal of an electron from $\mathrm{Mn} 2$ should be much more energetically demanding than the removal of an electron from $\mathrm{Mn} 1$, that is, the oxidation should preferentially affect the organometallic Mn1 part of the investigated compounds (Figure 9). However, the situation for the resulting $\mathrm{Mn}^{\mathrm{II}} \mathrm{Mn}^{\mathrm{II}}$ species is not clear because the oxidation can lead to septet and quintet electronic states in which the two $\mathrm{Mn}^{\mathrm{II}}$ centers are coupled ferromagnetically or antiferromagnetically, respectively.

To provide a comprehensive description of these highly unsymmetric systems, calculated charge and spin distributions of the investigated compounds are listed in Tables 4 and 5. Several conclusions can be drawn from those data. In the neutral and cationic species, both types of complexes, 3 and 5, display essentially the same spin and charge distributions. Irrespective of the functional, spin contamination is low for the calculated sextet and septet states. The $\left\langle S^{2}\right\rangle$ values of ${ }^{\mathbf{6}} \mathbf{3}$ and ${ }^{\mathbf{6}} \mathbf{5}(8.754-8.758)$ as well as those of ${ }^{7} \mathbf{3}^{+}$and ${ }^{7} \mathbf{5}^{+}(12.016-12.025)$ are only slightly larger than 8.75 and 12.00 , respectively. For ${ }^{\mathbf{6}} \mathbf{3}$ and ${ }^{\mathbf{6}} \mathbf{5}$ the atomic spin densities $(\rho)$ are negligible for the $\mathrm{Mn} 1$ atom $(0.007-0.018)$, whereas $\rho$ values of Mn2 (4.656-4.791) confirm the almost 


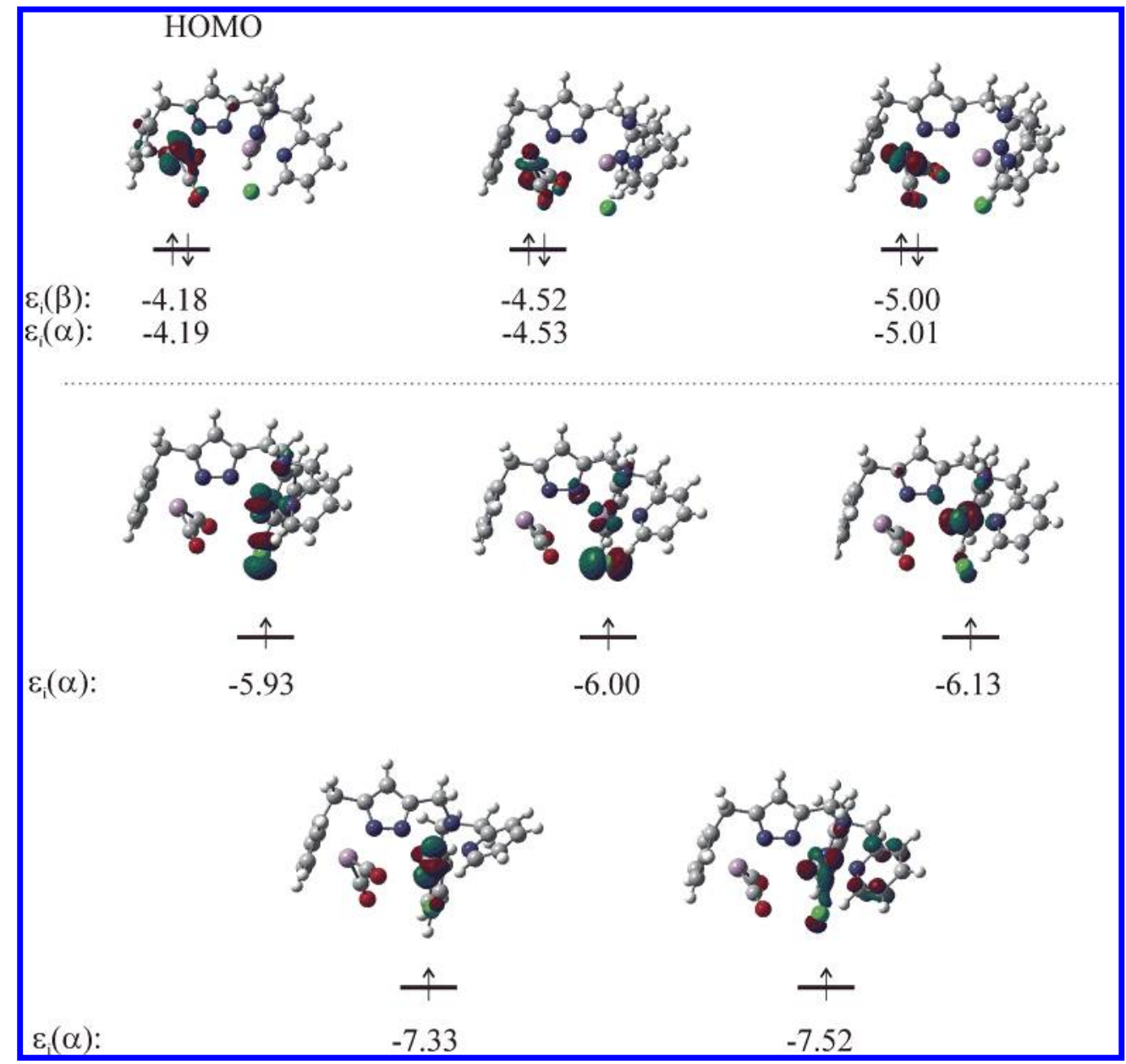

Figure 9. Occupation patterns, shapes, and energies $\epsilon_{\mathrm{i}}(\mathrm{eV})$ of the valence $\alpha$ and $\beta$ Kohn-Sham MOs, with predominant Mn1 (top) and Mn2 (bottom) character derived from the unrestricted B3LYP/6-311G* wave function of ${ }^{\mathbf{3}}$.

Table 4. Relative Energies $\left(\mathrm{kcal} \mathrm{mol}^{-1}\right)$, Expectation Values of the $\left\langle S^{2}\right\rangle$ Operator, Mulliken Atomic Spin Densities $(\rho)$, and Mulliken Charges $(q)$ of the Mn Atoms and Ligands for the Optimized Structures of ${ }^{\mathbf{6}},{ }^{\mathbf{7}} \mathbf{3}^{+}$, and ${ }^{\mathbf{5}} \mathbf{3}^{+}$and for ${ }^{\mathbf{2}}$ (6-311G* Basis Set)

\begin{tabular}{|c|c|c|c|c|c|c|c|c|}
\hline & \multicolumn{2}{|c|}{${ }^{2} 3^{a}$} & \multicolumn{2}{|c|}{${ }^{6} 3$} & \multicolumn{2}{|c|}{${ }^{7} 3+$} & \multicolumn{2}{|c|}{${ }^{5} 3+$} \\
\hline & B3LYP & BP86 & B3LYP & BP86 & B3LYP & BP86 & B3LYP & BP86 \\
\hline$E_{\text {rel }}$ & +59.7 & +51.7 & 0.0 & 0.0 & +110.2 & +119.4 & +110.3 & +119.3 \\
\hline$\left\langle S^{2}\right\rangle^{b}$ & $\begin{array}{l}0.780 \\
(0.750)\end{array}$ & $\begin{array}{l}0.847 \\
(0.754)\end{array}$ & $\begin{array}{l}8.755 \\
(8.750)\end{array}$ & $\begin{array}{l}8.758 \\
(8.750)\end{array}$ & $\begin{array}{l}12.025 \\
(12.000)\end{array}$ & $\begin{array}{l}12.017 \\
(12.000)\end{array}$ & $\begin{array}{l}7.045 \\
(6.026)\end{array}$ & $\begin{array}{l}6.938 \\
(6.015)\end{array}$ \\
\hline$\rho \mathrm{Mn} 1 / \mathrm{Mn} 2$ & $0.000 /$ & $-0.014 /$ & $0.010 /$ & $0.018 /$ & $1.024 /$ & $0.854 /$ & $-1.020 /$ & $-0.778 /$ \\
\hline & 1.019 & 1.127 & 4.760 & 4.656 & 4.763 & 4.646 & 4.765 & 4.573 \\
\hline$\rho \mathrm{N} 1 / \mathrm{N} 2$ & $0.001 /$ & $0.000 /$ & $0.002 /$ & $0.004 /$ & $-0.006 /$ & $0.026 /$ & $0.010 /$ & $-0.014 /$ \\
\hline & -0.016 & -0.024 & 0.015 & 0.022 & 0.006 & 0.007 & 0.025 & 0.033 \\
\hline$\rho \mathrm{Cl}$ & -0.026 & -0.033 & 0.053 & 0.077 & 0.062 & 0.093 & 0.063 & 0.092 \\
\hline$q \mathrm{Mn} 1 / \mathrm{Mn} 2$ & $+0.960 /$ & $+0.918 /$ & $+0.957 /$ & $+0.907 /$ & $+1.021 /$ & $+0.949 /$ & $+1.021 /$ & $+0.944 /$ \\
\hline & +1.311 & +1.240 & +1.433 & +1.371 & +1.426 & +1.363 & +1.426 & +1.377 \\
\hline$q \mathrm{~L}^{c}$ & -0.482 & -0.415 & -0.515 & -0.457 & -0.474 & -0.396 & -0.475 & -0.400 \\
\hline$q \mathrm{Cp}$ & -0.407 & -0.337 & -0.404 & -0.339 & -0.142 & -0.067 & -0.142 & -0.081 \\
\hline$q \mathrm{CO}(1) / \mathrm{CO}(2)$ & $-0.337 /$ & $-0.345 /$ & $-0.339 /$ & $-0.351 /$ & $-0.115 /$ & $-0.164 /$ & $-0.114 /$ & $-0.178 /$ \\
\hline & -0.286 & -0.306 & -0.286 & -0.307 & -0.070 & -0.114 & -0.070 & -0.129 \\
\hline$q \mathrm{Cl}$ & -0.674 & -0.584 & -0.720 & -0.670 & -0.719 & -0.662 & -0.719 & -0.640 \\
\hline
\end{tabular}

${ }^{a}$ Single-point calculations with optimized geometry of the corresponding sextet state. ${ }^{b}$ Values in parentheses refer to $\left\langle S^{2}\right\rangle$ after annihilation of the first spin contaminant. ${ }^{c} \mathrm{~L}=$ bridging pyrazolate.

perfectly localized nature of the unpaired spin. As expected, the doublet state $\mathbf{2} 3$ is $59.5 \mathrm{kcal} \mathrm{mol}^{-1}$ (B3LYP) or $51.7 \mathrm{kcal}$ $\mathrm{mol}^{-1}$ (BP86) higher in energy than the sextet state ${ }^{\mathbf{6}}$. Complex ${ }^{\mathbf{2}} \mathbf{3}$ is plagued by larger spin contamination than the sextet state, 63. Hence, the doublet state was not considered for $\mathbf{5}$. It should also be noted that spin contamination of ${ }^{2} \mathbf{3}$ is larger at the BP86 level $\left(\left\langle S^{2}\right\rangle=0.847\right)$ than at the B3LYP level $\left(\left\langle S^{2}\right\rangle=0.780\right)$ (Table 4$)$.
Removal of an electron from the $\mathbf{6} \mathbf{3}$ ground state to give ${ }^{7} 3^{+}$requires $110.2 \mathrm{kcal} \mathrm{mol}^{-1}(\mathrm{~B} 3 \mathrm{LYP})$ or $119.4 \mathrm{kcal} \mathrm{mol}^{-1}$ (BP86) (Table 4). In accord with electrochemical measurements (Table 2, vide supra), almost the same energy is needed to produce ${ }^{7} \mathbf{5}^{+}$[109.2 $\mathrm{kcal} \mathrm{mol}^{-1}$ (B3LYP), 117.4 kcal mol ${ }^{-1}$ (BP86)] (Table 5). From Tables 4 and 5 it is evident that the septet or quintet states of the cationic species arise by removal of an electron from the Mn1 center. The 
Sheng et al.

Table 5. Relative Energies ( $\mathrm{kcal} \mathrm{mol}^{-1}$ ), Expectation Values of the $\left\langle S^{2}\right\rangle$ Operator, Mulliken Atomic Spin Densities $(\rho)$, and Mulliken Charges $(q)$ of the Mn Atoms and Ligands for the 6-311G* Optimized Structures of ${ }^{\mathbf{6}}$ and $^{\mathbf{7}} \mathbf{5}^{+}$

\begin{tabular}{|c|c|c|c|c|}
\hline & \multicolumn{2}{|c|}{65} & \multicolumn{2}{|c|}{${ }^{7} 5^{+}$} \\
\hline & B3LYP & BP86 & B3LYP & BP86 \\
\hline$E_{\mathrm{rel}}$ & 0.0 & 0.0 & +109.2 & +117.4 \\
\hline$\left\langle S^{2}\right\rangle^{a}$ & $8.754(8.750)$ & $8.756(8.750)$ & $12.024(12.000)$ & $12.016(12.000)$ \\
\hline$\rho \mathrm{Mn} 1 / \mathrm{Mn} 2$ & $0.007 / 4.791$ & $0.012 / 4.687$ & $1.043 / 4.772$ & $0.843 / 4.687$ \\
\hline$\rho \mathrm{N} 1 / \mathrm{N} 2$ & $0.023 / 0.018$ & $0.004 / 0.024$ & $-0.002 / 0.003$ & $0.033 / 0.003$ \\
\hline$\rho \mathrm{O}(3) / \mathrm{O}(4)_{\mathrm{Oac}}$ & $0.041 / 0.023$ & $0.033 / 0.030$ & $0.064 / 0.030$ & $0.035 / 0.032$ \\
\hline$q \mathrm{Mn} 1 / \mathrm{Mn} 2$ & $+0.968 /+1.463$ & $+0.917 /+1.403$ & $+1.019 /+1.465$ & $+0.947 /+1.447$ \\
\hline$q \mathrm{~L}^{b}$ & -0.525 & -0.474 & -0.463 & -0.383 \\
\hline$q \mathrm{Cp}$ & -0.410 & -0.352 & -0.148 & -0.078 \\
\hline$q \mathrm{CO}(1) / \mathrm{CO}(2)$ & $-0.315 /-0.299$ & $-0.371 /-0.306$ & $-0.159 /-0.062$ & $-0.180 /-0.104$ \\
\hline$q \mathrm{O}(3) / \mathrm{O}(4)_{\mathrm{Oac}}$ & $-0.524 /-0.543$ & $-0.470 /-0.491$ & $-0.553 /-0.558$ & $-0.466 /-0.496$ \\
\hline
\end{tabular}

${ }^{a}$ Values in parentheses refer to $\left\langle S^{2}\right\rangle$ after annihilation of the first spin contaminant. ${ }^{b} \mathrm{~L}=$ bridging pyrazolate.

spin density of Mn2 (4.573-4.772) does not differ much from that in the neutral species $(4.656-4.791)$, and the spin density of Mn1 changes to $0.843-1.024$ in ${ }^{7} \mathbf{3}^{+}$and ${ }^{7} \mathbf{5}^{+}$or to -1.020 to -0.778 in ${ }^{5} \mathbf{3}^{+}$. Spin distributions calculated with the B3LYP functional are more localized than those from the BP86 level. For both functionals, the septet and quintet states of $\mathbf{3}^{+}$are very close in energy. At the B3LYP level ${ }^{7} \mathbf{3}^{+}$is $0.1 \mathrm{kcal} \mathrm{mol}^{-1}$ more stable than ${ }^{\mathbf{5}} \mathbf{3}^{+}$, whereas at the BP86 level the situation is reversed, indicating a possible antiferromagnetic interaction between the metal centers. The $J_{\mathrm{ab}}$ values, calculated according to the broken-symmetry formalism of Noodleman ${ }^{26}$ and the spin projection procedure of Yamaguchi, ${ }^{27}$ amount to $-6.9 \mathrm{~cm}^{-1}$ (BP86), and +7.0 $\mathrm{cm}^{-1}$ (B3LYP). Because it was not possible to either isolate the oxidized species or determine the $J_{\mathrm{ab}}$ value experimentally, the preferred coupling between the electrons of $\mathrm{Mn} 1$ and Mn2 could not be deduced from the conflicting B3LYP and BP86 values. As has been reported for DFT calculations on other oligonuclear complexes in low-spin broken-symmetry states, ${ }^{28} \mathbf{5}^{+}$suffers from large spin contamination. The calculated $\left\langle S^{2}\right\rangle$ values of 7.045 (B3LYP) and 6.938 (BP86) are far from 6 . As an example, the calculated total spin densities of ${ }^{\mathbf{6}} \mathbf{3},{ }^{\mathbf{7}} \mathbf{3}^{+}$, and ${ }^{\mathbf{5}} \mathbf{3}^{+}$are graphically depicted in Figure 10.

At the B3LYP level, ${ }^{\mathbf{7}} \mathbf{3}^{+}$and $\mathbf{5 3}^{+}$have essentially the same carbonyl ligand bonding parameters and display identical IR spectra in the $v(\mathrm{C} \equiv \mathrm{O})$ stretching region, but small differences are discernible at the BP86 level (see below).

The removal of an electron from Mn1 does not significantly influence the charge and spin distribution on $\mathrm{Mn} 2$ (Tables 4 and 5). However, in the cationic species ${ }^{7} \mathbf{3}^{+/ 53^{+}}$ and $\mathbf{7}^{\mathbf{5}}$, electron density flows from the surrounding ligands toward $\mathrm{Mn} 1$ and compensates for the loss of electron density that occurs upon oxidation. Compared to the neutral com-

(26) (a) Noodleman, L.; Peng, C. Y.; Case, D. A.; Mouesca, J.-M. Coord. Chem. Rev. 1995, 144, 199-244 and references cited. (b) Ruiz, E.; Cano, J.; Alvarez, S.; Alemany, P. J. Comput. Chem. 1999, 20, 13911400 .

(27) (a) Nishino, M.; Yamanaka, S.; Yoshioka, Y.; Yamaguchi, K. J. Phvs. Chem. A. 1997, 101, 705-712. (b) Onishi, T.; Takano, Y.; Kitagawa, Y.; Kawakami, T.; Yoshioka, Y.; Yamaguchi, K. Polvhedron 2001, 20, 1177-1184. (c) Takano, Y.; Kitagawa, Y.; Onishi, T.; Yoshioka, Y.; Yamaguchi, K.; Koga, N.; Iwamura, H. J. Am. Chem. Soc. 2002, $124,450-461$.

(28) (a) Bühl, M.; Thiel, W. Inorg. Chem. 2004, 43, 6377-6382. (b) Kiehl, P.; Rohmer, M.-M.; Benard, M. Inorg. Chem. 2004, 43, 3151-3158.

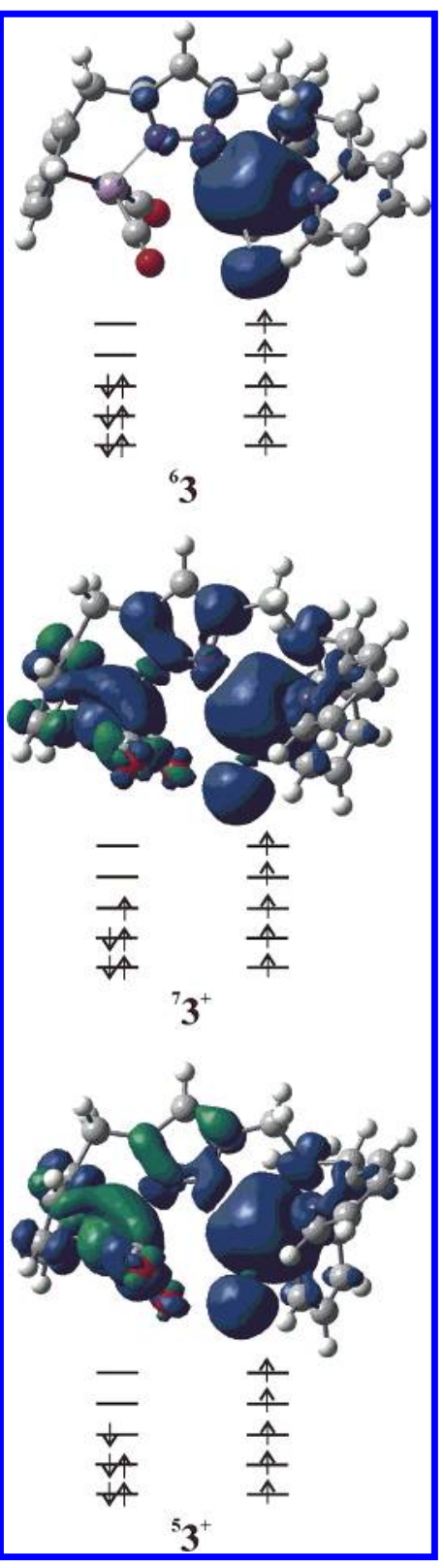

Figure 10. Total spin densities and occupation patterns of Mn1(3d) and Mn2(3d) Kohn-Sham MOs derived from the B3LYP/6-311G* wave functions of ${ }^{6} \mathbf{3},{ }^{7} 3^{+}$, and ${ }^{5} 3^{+}$. Colors blue and green refer to $\alpha$ - and $\beta$-spin density, respectively. The isosurface plots are at 0.0008 esu $\AA^{-3}$.

plexes, there is only a small increase in the positive charge on the Mn1 in ${ }^{\mathbf{7}} \mathbf{3}^{+} / \mathbf{5} \mathbf{3}^{+}$and ${ }^{7} \mathbf{5}^{+}$, but a significant depletion 
Table 6. Optimized Parameters of ${ }^{\mathbf{5}^{+}},{ }^{\mathbf{7}} \mathbf{3}^{+}$, and ${ }^{\mathbf{7}} \mathbf{5}^{+}\left(6-311 \mathrm{G}^{*}\right.$ Basis Set $)^{a}$

\begin{tabular}{|c|c|c|c|c|c|c|}
\hline & \multicolumn{2}{|c|}{$\mathbf{5 3}^{+}$} & \multicolumn{2}{|c|}{${ }^{7} 3^{+}$} & \multicolumn{2}{|c|}{${ }^{7} 5^{+}$} \\
\hline & B3LYP & BP86 & B3LYP & BP86 & B3LYP & BP86 \\
\hline $\mathrm{Mn} 1-\mathrm{N} 1$ & 1.967 & 1.944 & 1.967 & 1.937 & 1.960 & 1.934 \\
\hline $\mathrm{Mn} 2-\mathrm{N} 2$ & 2.169 & 2.132 & 2.167 & 2.141 & 2.223 & 2.212 \\
\hline $\mathrm{Mn} 2-\mathrm{Cl} / \mathrm{Mn} 2-\mathrm{O}_{\mathrm{OAc}}{ }^{b}$ & 2.326 & 2.284 & 2.326 & 2.295 & 2.219 & 2.207 \\
\hline $\mathrm{Mn} 2-\mathrm{N} 4 / \mathrm{N} 5^{b}$ & 2.232 & 2.196 & 2.322 & 2.206 & 2.274 & 2.245 \\
\hline $\mathrm{Mn} 1-\mathrm{C}_{\mathrm{C} \equiv \mathrm{O}(1)}$ & 1.853 & 1.806 & 1.853 & 1.809 & 1.853 & 1.796 \\
\hline $\mathrm{Mn} 1-\mathrm{C}_{\mathrm{C} \equiv \mathrm{O}(2)}$ & 1.870 & 1.815 & 1.870 & 1.822 & 1.877 & 1.826 \\
\hline $\mathrm{Mn} 1-\mathrm{C}(\mathrm{Cp})^{b}$ & 2.171 & 2.154 & 2.171 & 2.156 & 2.172 & 2.157 \\
\hline $\mathrm{C}_{\mathrm{C} \equiv \mathrm{O}}-\mathrm{O}(1)$ & 1.139 & 1.161 & 1.138 & 1.159 & 1.143 & 1.164 \\
\hline $\mathrm{C}_{\mathrm{C} \equiv \mathrm{O}}-\mathrm{O}(2)$ & 1.135 & 1.157 & 1.135 & 1.156 & 1.135 & 1.155 \\
\hline $\mathrm{N} 1-\mathrm{N} 2$ & 1.364 & 1.371 & 1.363 & 1.371 & 1.362 & 1.369 \\
\hline$\angle \mathrm{C}_{\mathrm{C} \equiv \mathrm{O}(1)}-\mathrm{Mn} 1-\mathrm{N} 1$ & 97.3 & 98.5 & 97.3 & 98.5 & 97.2 & 98.3 \\
\hline$\angle \mathrm{C}_{\mathrm{C} \equiv \mathrm{O}(2)}-\mathrm{Mn} 1-\mathrm{N} 1$ & 99.1 & 100.1 & 99.2 & 100.4 & 99.2 & 101.0 \\
\hline$\angle \mathrm{Mn} 1-\mathrm{N} 1-\mathrm{N} 2$ & 133.2 & 132.3 & 133.2 & 132.3 & 133.1 & 132.4 \\
\hline$\angle \mathrm{Mn} 2-\mathrm{N} 2-\mathrm{N} 1$ & 136.6 & 136.4 & 136.5 & 135.9 & 136.1 & 136.4 \\
\hline$\angle \mathrm{Mn} 1-\mathrm{N} 1-\mathrm{N} 2-\mathrm{Mn} 2$ & 3.5 & 3.9 & 3.2 & 2.4 & -10.0 & -6.1 \\
\hline
\end{tabular}

${ }^{a}$ Distances are given in $[\AA ̊]$, angles in degrees. ${ }^{b}$ Mean values.

of electron density is observed for the cyclopentadienyl, pyrazolate, and carbonyl ligands. It is clear that for the carbonyl ligands, such reorganization of electron density leads to diminished back-bonding interactions, which of course should be reflected by the changes in the Mn1- $\mathrm{C}_{\mathrm{C}} \equiv$ $\mathrm{o}$ and $\mathrm{C} \equiv \mathrm{O}$ bond distances and in the carbonyl stretching vibrations. Optimized geometrical parameters of the cationic species ${ }^{5} \mathbf{3}^{+},{ }^{\mathbf{7}} \mathbf{3}^{+}$, and ${ }^{\mathbf{7}} \mathbf{5}^{+}$are collected in Table 6 .

With respect to the neutral complexes, both functionals predict an elongation of $\mathrm{Mn} 1-\mathrm{C}_{\mathrm{C} \equiv \mathrm{O}}$ bonds and a shortening of $\mathrm{C} \equiv \mathrm{O}$ distances for the cationic species. Although the shortening of the $\mathrm{C} \equiv \mathrm{O}$ bond distances is comparable at both levels of calculation [0.019-0.024 $\AA$ (B3LYP); 0.018-0.021 $\AA$ (BP86)], the elongation of $\mathrm{Mn} 1-\mathrm{C}_{\mathrm{C} \equiv \mathrm{O}}$ bonds is almost two times larger at the B3LYP level $(0.077-0.095 \AA)$ than at the BP86 level $(0.034-0.055 \AA)$. As in the neutral complexes, bonds between the low-spin $\mathrm{d}^{5} \mathrm{Mn} 1$ ion and the pyrazolate-N1 (1.934-1.967 $\AA$ ) are significantly shorter than those between the high-spin $\mathrm{d}^{5} \mathrm{Mn} 2$ ion and the pyrazolate-N2 $(2.132-2.223 \AA)$. Because the Mn1-N1 distance is shorter in $\mathbf{5}^{+}, \mathbf{7}^{+}$, and ${ }^{\mathbf{7}} \mathbf{5}^{+}$than in the neutral complexes, whereas the Mn2-N2 distance is longer, the difference between the $\mathrm{Mn} 1-\mathrm{N} 1$ and the $\mathrm{Mn} 2-\mathrm{N} 2$ bond distances is more pronounced in the cationic species. Although an electron is removed from $\mathrm{Mn} 1$, the oxidation also influences the bond parameters of the Mn2 ligation sphere in the investigated compounds.

The CO stretching vibrations calculated with the $6-311 \mathrm{G}$ basis set appear at lower values than the experiment ones (Table 7). Compared to the experiment, the red shift of B3LYP/6-311G frequencies $\left(11-39 \mathrm{~cm}^{-1}\right)$ is more systematic than that at the BP86/6-311G level $\left(89-147 \mathrm{~cm}^{-1}\right)$. The inclusion of polarization functions in the basis set leads to blue shifted values for $\mathrm{CO}$ vibrations. The absolute values of BP86/6-311G* frequencies are closer to the experimental values than those of B3LYP/6-311G* frequencies. Because at this point we compare the theoretical harmonic frequencies with the experimental (anharmonic) fundamentals, the agreement between the BP86 results and those of the experiment may benefit from error cancellation. The same is valid for
B3LYP/6-311G frequencies, which, apart from a blue shift averaging $28 \mathrm{~cm}^{-1}$, agree very well with experiment. The B3LYP/6-311G* frequencies are systematically too high by $\sim 6-7 \%$ relative to the experimental values. It is commonly thought that such overestimation is mainly due to the anharmonicity, which can be approximately accounted for by scaling the harmonic frequencies. ${ }^{29}$ In Figure 11 we compare the B3LYP/6-311G* frequencies scaled by 0.94 with the experimental IR data of the neutral complexes $\mathbf{3}$ and $\mathbf{5}$ and of their oxidized forms $\mathbf{3}^{+}$and $\mathbf{5}^{+}$. With respect to the relative intensities of the asymmetric $\left(v_{\mathrm{as}}\right)$ and symmetric $\left(v_{\mathrm{s}}\right)$ CO stretches, the separation $\left[\Delta\left(v_{\mathrm{s}}-v_{\mathrm{as}}\right)\right]$ for the neutral $(\mathbf{3}, \mathbf{5})$ and cationic $\left(\mathbf{3}^{+}, \mathbf{5}^{+}\right)$species, as well as the shift of $\mathrm{CO}$ vibrations due to oxidation $\left[\Delta v_{\mathrm{as} / \mathrm{s}}\left(\mathbf{3}^{+}-\right.\right.$ 3) and $\left.\Delta v_{\text {as } / s}\left(\mathbf{5}^{+}-\mathbf{5}\right)\right]$, the patterns of the experimental spectra are well-reproduced by the B3LYP/6-311G* calculations (Table 7, Figure 11). It should also be noticed that both functionals and basis sets reproduce the trends of relative band intensities observed in the experimental spectra rather well.

Compared to BP86, the experimental separation between the corresponding symmetric and asymmetric modes is more accurately reproduced at the B3LYP level. The scaling of B3LYP/6-311G* frequencies increases the accuracy of the blue shift of $v(\mathrm{CO})$ vibrations due to oxidation. Similar to other studies, ${ }^{28 a}$ the BP86 functional systematically underestimates that blue shift of $v(\mathrm{CO})$ vibrations upon oxidation, and consequently the B3LYP IR spectroscopic properties of $3, \mathbf{5}, \mathbf{3}^{+}$, and $\mathbf{5}^{+}$are in better agreement with the experiment than those found using the BP86 functional(Table 7).

\section{Conclusions}

In this work we describe a detailed experimental and theoretical analysis of the molecular and electronic structure of hybrid organometallic/Werner-type dimanganese complexes, $\mathrm{L}^{\mathrm{Mn}} \mathrm{MnX}$, in their $\mathrm{Mn}^{\mathrm{I}} \mathrm{Mn}^{\mathrm{II}}$ and $\mathrm{Mn}^{\mathrm{II}} \mathrm{Mn}^{\mathrm{II}}$ states. Despite a short $\mathrm{Mn} \cdots \mathrm{Mn}$ separation of $\sim 4.3 \AA$ and a pyrazolate bridge that is known to be a good electronic coupler, an almost perfectly localized electronic structure is enforced by the highly unsymmetric ligand scaffold, which is supported by crystallographic and spectroscopic evidence as well as DFT calculations. The mixed-valent $\mathrm{Mn}^{\mathrm{I}} \mathrm{Mn}^{\mathrm{II}}$ state in these complexes is extremely stabilized but with the spin fully localized on the Werner-type high-spin $\mathrm{Mn}^{\mathrm{II}}$ ion. Oxidation occurs exclusively at the organometallic $\mathrm{Mn}^{\mathrm{I}}$ site to give the low-spin/high-spin $\mathrm{Mn}^{\mathrm{II}} \mathrm{Mn}^{\mathrm{II}}$ species, but this process does not significantly influence the spin and charge distribution on the Werner-type site. These systems thus represent exceptional examples of the effect the unsymmetry of a dinucleating ligand scaffold has on the spin and charge distribution in homobimetallic complexes. Furthermore, the strict site control of the redox process might offer interesting prospects for the study of cooperative effects of bimetallic arrays (e.g., in reactions that proceed via substrate binding at the Werner-type site with the adjacent organometallic

(29) Jensen, F.; Introduction to Computational Chemistry; Wiley: Chichester, England, 1999; pp. 271-274. 
Sheng et al.

Table 7. Properties of the Calculated CO Frequencies $\left(\mathrm{cm}^{-1}\right)$ of $\mathbf{6}^{\mathbf{3}}, \mathbf{7}^{+}, \mathbf{5}^{+},{ }^{\mathbf{6}}$, and ${ }^{\mathbf{7}} \mathbf{5}^{+}$in Comparison with Experimental IR Data ${ }^{a}$

\begin{tabular}{|c|c|c|c|c|c|c|}
\hline & & $\exp$ & B3LYP/6-311G & B3LYP/6-311G* & BP86/6-311G & BP86/6-311G* \\
\hline${ }^{6} \mathbf{3}$ & $\begin{array}{l}v_{\mathrm{as}} \\
v_{\mathrm{s}} \\
\Delta\left(v_{\mathrm{s}}-\nu_{\mathrm{as}}\right)\end{array}$ & $\begin{array}{c}1834(1.0) \\
1908(0.8) \\
74\end{array}$ & $\begin{array}{c}1813(1.0) \\
1878(0.6) \\
65\end{array}$ & $\begin{array}{c}1956(1.0) \\
2020(0.7) \\
64\end{array}$ & $\begin{array}{c}1745(1.0) \\
1796(0.6) \\
51\end{array}$ & $\begin{array}{c}1875(1.0) \\
1925(0.6) \\
50\end{array}$ \\
\hline${ }^{7} \mathbf{3}^{+} / 53^{+}$ & $\begin{array}{l}v_{\mathrm{as}} \\
v_{\mathrm{s}} \\
\Delta\left(v_{\mathrm{s}}-v_{\mathrm{as}}\right)\end{array}$ & $\begin{array}{c}1952(0.7) \\
2029(0.6) \\
77\end{array}$ & $\begin{array}{c}1941(0.8) / 1942(0.8) \\
1996(0.5) / 1996(0.5) \\
55 / 54\end{array}$ & $\begin{array}{c}2098(0.7) / 2098(0.7) \\
2149(0.5) / 2148(0.5) \\
51 / 50\end{array}$ & $\begin{array}{c}1830(0.9) / 1812(0.9) \\
1885(0.6) / 1846(0.9) \\
55 / 34\end{array}$ & $\begin{array}{c}1973(0.9) / 1964(0.8) \\
2025(0.6) / 1997(0.9) \\
52 / 33\end{array}$ \\
\hline \multicolumn{2}{|c|}{ 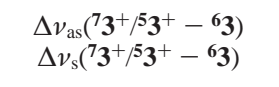 } & $\begin{array}{l}118 \\
121\end{array}$ & $\begin{array}{l}128 / 129 \\
118 / 118\end{array}$ & $\begin{array}{l}142 / 142 \\
129 / 128\end{array}$ & $\begin{array}{l}85 / 67 \\
89 / 50\end{array}$ & $\begin{array}{c}98 / 89 \\
100 / 72\end{array}$ \\
\hline 65 & $\begin{array}{l}v_{\text {as }} \\
v_{\mathrm{s}} \\
\Delta\left(v_{\mathrm{s}}-v_{\mathrm{as}}\right)\end{array}$ & $\begin{array}{c}1834(1.0) \\
1908(0.8) \\
74\end{array}$ & $\begin{array}{c}1808(1.0) \\
1869(0.7) \\
61\end{array}$ & $\begin{array}{c}1950(1.0) \\
2011(0.8) \\
61\end{array}$ & $\begin{array}{c}1741(1.0) \\
1791(0.7) \\
50\end{array}$ & $\begin{array}{c}1868(1.0) \\
1921(0.8) \\
53\end{array}$ \\
\hline $\mathbf{7 5}^{+}$ & $\begin{array}{l}v_{\text {as }} \\
v_{\mathrm{s}} \\
\Delta\left(v_{\mathrm{s}}-v_{\mathrm{as}}\right)\end{array}$ & $\begin{array}{c}1951(0.5) \\
2029(0.4) \\
78\end{array}$ & $\begin{array}{c}1920(0.7) \\
1994(0.6) \\
74\end{array}$ & $\begin{array}{c}2074(0.8) \\
2146(0.6) \\
72\end{array}$ & $\begin{array}{c}1814(0.9) \\
1882(0.7) \\
68\end{array}$ & $\begin{array}{l}1954(0.9) \\
2022(0.8) \\
68\end{array}$ \\
\hline \multicolumn{2}{|c|}{$\begin{array}{l}\Delta v_{\mathrm{as}}\left(7 \mathbf{5}^{+}-{ }^{6 \mathbf{5}}\right) \\
\Delta v_{\mathrm{s}}\left(\mathbf{7}^{+}-\mathbf{6 5}^{+}\right)\end{array}$} & $\begin{array}{l}117 \\
121\end{array}$ & $\begin{array}{l}112 \\
125\end{array}$ & $\begin{array}{l}124 \\
135\end{array}$ & $\begin{array}{l}73 \\
91\end{array}$ & $\begin{array}{c}86 \\
101\end{array}$ \\
\hline
\end{tabular}

${ }^{a}$ Relative intensities are given in parentheses.

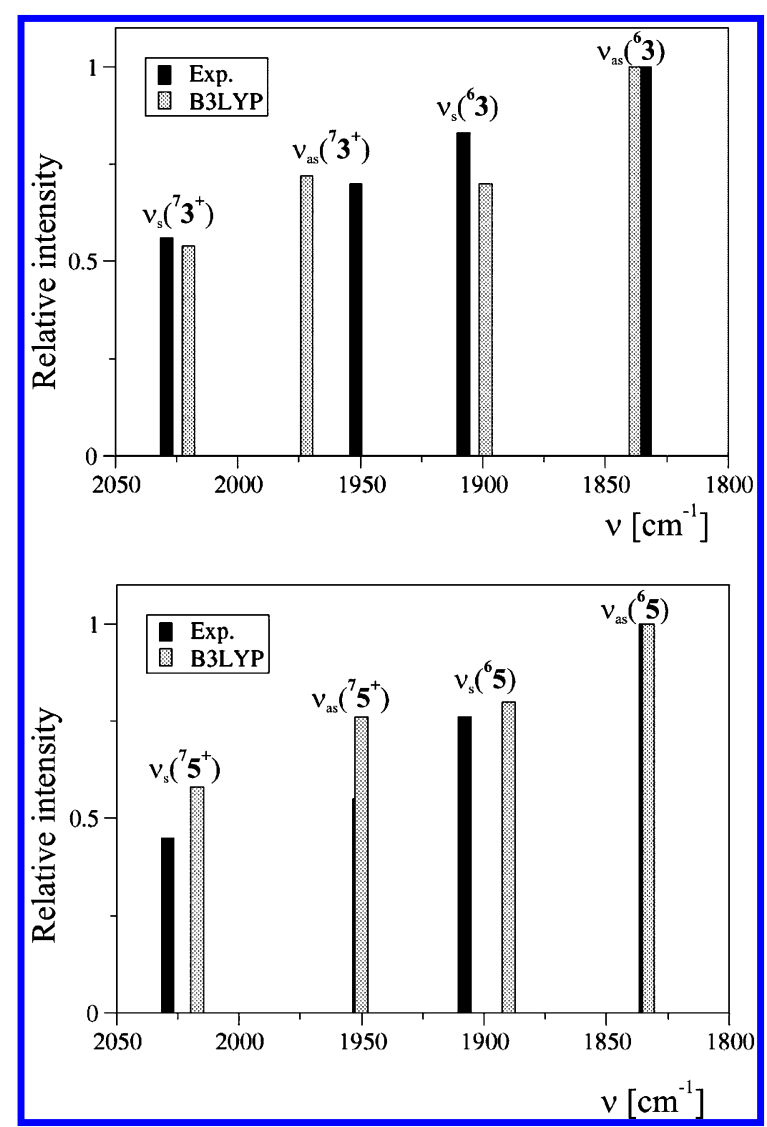

Figure 11. Schematic comparison of the experimental and calculated $\mathrm{CO}$ frequencies of ${ }^{\mathbf{3}}$ and ${ }^{\mathbf{7}} \mathbf{3}^{+}$(top) and of $\mathbf{6}^{\mathbf{5}}$ and ${ }^{\mathbf{7}} \mathbf{5}^{+}$(bottom) (B3LYP/6$311 \mathrm{G}^{*}$ results scaled by 0.94$)$.

subunit solely acting as a redox reservoir). Work along these lines is presently in progress.

\section{Experimental Section}

General Procedures and Methods. All manipulations were carried out under an atmosphere of dry nitrogen by employing standard Schlenk techniques. Compound $\mathbf{2}$ was prepared as reported..$^{11}$ Solvents were dried according to established procedures; all other chemicals were obtained from commercial sources and used as received. Microanalyses were carried out at the Mikroana- lytische Laboratorien des Anorganisch-Chemischen Instituts der Universität Göttingen using a Heraeus CHN-O-RAPID. Cyclic voltammetry: PAR equipment (potentiostat/galvanostat 263A), in $\sim 0.1 \mathrm{M} \mathrm{NBu}_{4} \mathrm{PF}_{6} / \mathrm{CH}_{2} \mathrm{Cl}_{2}$, using a glassy carbon working electrode and platinum reference and counter electrodes; ferrocene $\mathrm{Cp}_{2} \mathrm{Fe}$ was used as the internal standard (the potential being $0.45 \mathrm{~V}$ in DMF against an SCE electrode).$^{30}$ IR spectra: Digilab Excalibur, recorded as $\mathrm{KBr}$ pellets or in solution between $\mathrm{NaCl}$ plates. UV/ vis spectra: Cary 5000 UV/vis-NIR spectrophotometer. Spectroelectrochemistry: self-constructed OTTLE cell comprising Pt-mesh working and counter electrodes and a silver wire as a pseudoreference electrode sandwiched between the $\mathrm{CaF}_{2}$ windows of a conventional liquid IR cell. The working electrode is positioned in the center of the spectrometer beam, and all other parts of the cell are made nontransparent to the incident beam by means of an absorbing tape. ${ }^{31}$

Caution! Although no problems were encountered in this work, transition-metal perchlorate salts and complexes are potentially explosive and should be handled with proper precautions.

$\mathbf{L}^{\mathrm{Mn}} \mathbf{M n C l}(\mathbf{3})$. A solution of $\mathbf{2}(0.25 \mathrm{~g}, 0.50 \mathrm{mmol})$ in tetrahydrofuran (THF; $200 \mathrm{~mL}$ ) was irradiated with a high-pressure mercury lamp in a quartz tube at $-40{ }^{\circ} \mathrm{C}$. Within $\sim 1 \mathrm{~h}$ the color of the solution changed from light yellow to yellow, and the solution was then allowed to warm to room temperature. KOtBu $(0.056 \mathrm{~g}$, $0.50 \mathrm{mmol})$ and $\mathrm{MnCl}_{2} \cdot 4 \mathrm{H}_{2} \mathrm{O}(0.098 \mathrm{~g}, 0.50 \mathrm{mmol})$ were added, and the mixture was stirred overnight, producing a yellow precipitate. The precipitate was separated by filtration, washed with light petroleum, and dried under vacuum. Orange-red crystals were obtained after several days by slow diffusion of diethyl ether into a DMF solution $(8 \mathrm{~mL})$ of the crude product. The crystals were separated by filtration, washed with diethyl ether, and dried under vacuum. Yield: $37 \mathrm{mg}(13 \%)$. IR (KBr) $\left(\mathrm{cm}^{-1}\right)$ : $2895 \mathrm{w}, 1909$ vs, 1836 vs, $1604 \mathrm{~m}, 1570 \mathrm{w}, 1446 \mathrm{~m}, 1437 \mathrm{~m}, 1339 \mathrm{~m}, 1311 \mathrm{~m}$, $1253 \mathrm{~m}, 1218 \mathrm{w}, 1149 \mathrm{~m}, 1010 \mathrm{~m}, 1051 \mathrm{~m}, 1016 \mathrm{~m}, 978$ w, 880 m, $823 \mathrm{~m}, 774 \mathrm{~m}, 761 \mathrm{~m}, 657 \mathrm{~m}, 609 \mathrm{~m}, 584 \mathrm{~m}, 411 \mathrm{~m}$. UV/vis $\lambda_{\max }, \mathrm{nm}\left(\epsilon_{\max }\right): 385\left(\mathrm{sh}, 0.775 \times 10^{3}\right), 283\left(\mathrm{sh}, 4.02 \times 10^{3}\right)$. Anal. $\mathrm{C}_{24} \mathrm{H}_{21} \mathrm{ClMn}_{2} \mathrm{~N}_{5} \mathrm{O}_{2}$ (556.79) (\%): calcd: C, 51.77; H, 3.80; N, 12.58; found: $\mathrm{C}, 50.33 ; \mathrm{H}, 3.93 ; \mathrm{N}, 12.35$.

(30) Connelly, N. G.; Geiger, W. E. Chem. Rev. 1996, 96, 877-910.

(31) Kreijcik, M.; Daniek, M.; Hartl, F. J. Electroanal. Chem. 1991, 317, 179. 
$\mathbf{L}^{\mathrm{Mn}} \mathbf{M n B r}$ (DMF) (4). This complex was prepared following the same procedure described for 3, but using $\mathrm{MnBr}_{2} \cdot 4 \mathrm{H}_{2} \mathrm{O}(0.143 \mathrm{~g}$, $0.50 \mathrm{mmol}$ ) instead of $\mathrm{MnCl}_{2} \cdot 4 \mathrm{H}_{2} \mathrm{O}$. Yield: $78 \mathrm{mg}(23 \%)$. IR $(\mathrm{KBr})$ $\left(\mathrm{cm}^{-1}\right)$ : $2931 \mathrm{w}, 1909 \mathrm{vs}, 1820 \mathrm{vs}, 1653 \mathrm{~s}, 1599 \mathrm{~m}, 1478 \mathrm{~m}, 1439$ m, 1385 m, 1336 m, 1290 m, 1260 w, 1154 w, 1011 m, $1051 \mathrm{~m}$, 1013 m, 908 w, 824 m, 768 m, 676 m, 661 m, 634 w, 611 m, 586 m, $410 \mathrm{~m}$. UV/vis $\lambda_{\max }, \mathrm{nm}\left(\epsilon_{\max }\right): 384\left(\mathrm{sh}, 0.773 \times 10^{3}\right), 285$ (sh, $4.33 \times 10^{3}$ ). Anal. $\mathrm{C}_{27} \mathrm{H}_{28} \mathrm{BrMn}_{2} \mathrm{~N}_{6} \mathrm{O}_{3}$ (674.34) (\%): calcd: $\mathrm{C}$, 48.09; H, 4.19; N, 12.46; found: C, 47.11; H, 4.18; N, 11.39.

$\mathbf{L}^{\mathrm{Mn}} \mathbf{M n}(\mathbf{O A c})$ (5). A solution of $2(0.25 \mathrm{~g}, 0.50 \mathrm{mmol})$ in THF (200 mL) was irradiated with a high-pressure mercury lamp in a quartz tube at $-40{ }^{\circ} \mathrm{C}$. Within $\sim 1 \mathrm{~h}$ the color of the solution changed from light yellow to yellow, and the solution was then allowed to warm to room temperature. $\mathrm{KOtBu}(0.056 \mathrm{~g}, 0.50 \mathrm{mmol})$ and $\mathrm{Mn}(\mathrm{OAc})_{2} \cdot 4 \mathrm{H}_{2} \mathrm{O}(0.123 \mathrm{~g}, 0.50 \mathrm{mmol})$ were added, and the reaction mixture was stirred overnight. The solvent was removed under vacuum, and the residue was extracted with dichloromethane (15 mL). Slow diffusion of diethyl ether into the filtrate gradually gave orange-red crystals of $\mathbf{5} \cdot \mathrm{CH}_{2} \mathrm{Cl}_{2}$. The crystals were separated by filtration, washed with diethyl ether, and dried under vacuum. Yield: $87 \mathrm{mg}(26 \%)$. IR (KBr) $\left(\mathrm{cm}^{-1}\right)$ : $2851 \mathrm{w}, 1907 \mathrm{vs}, 1832$ vs, 1605 s, $1570 \mathrm{~m}, 1542 \mathrm{~m}, 1477 \mathrm{~m}, 1438 \mathrm{~s}, 1341 \mathrm{~m}, 1313 \mathrm{w}$, 1269 m, 1218 w, 1158 m, 1129 w, 1101 w, 1054 m, 1015 m, 976 m, 954 w, $822 \mathrm{~m}, 770 \mathrm{~m}, 756 \mathrm{~m}, 723 \mathrm{~m}, 694 \mathrm{~m}, 677 \mathrm{~m}, 658 \mathrm{~m}$, $609 \mathrm{~m}, 586 \mathrm{~m}, 410 \mathrm{~m}$. UV/vis $\lambda_{\max }, \mathrm{nm}\left(\epsilon_{\max }\right): 384$ (sh, $0.729 \times$ $\left.10^{3}\right), 284$ (sh, $\left.4.05 \times 10^{3}\right)$. Anal. $\mathrm{C}_{27} \mathrm{H}_{26} \mathrm{Cl}_{2} \mathrm{Mn}_{2} \mathrm{~N}_{5} \mathrm{O}_{4}(665.32)$ (\%): calcd: C, 48.74; H, 3.94; N, 10.53; found: C, 47.81; H, 3.92; N, 10.10 .

$\left[\mathbf{L}^{\mathrm{Mn}} \mathrm{Mn}(\mathrm{DMF})_{2}\right]\left(\mathrm{ClO}_{4}\right)\left(\mathbf{6} \cdot \mathrm{ClO}_{4}\right)$. A solution of $\mathbf{2}(0.25 \mathrm{~g}, 0.50$ $\mathrm{mmol})$ in THF $(200 \mathrm{~mL})$ was irradiated with a high-pressure mercury lamp in a quartz tube at $-40{ }^{\circ} \mathrm{C}$. Within $\sim 1 \mathrm{~h}$ the color of the solution changed from light yellow to yellow, and the solution was then allowed to warm to room temperature. $\mathrm{KOtBu}(0.056 \mathrm{~g}$, $0.50 \mathrm{mmol})$ and $\mathrm{Mn}\left(\mathrm{ClO}_{4}\right)_{2} \cdot 6 \mathrm{H}_{2} \mathrm{O}(0.181 \mathrm{~g}, 0.50 \mathrm{mmol})$ were added, and the reaction mixture was stirred overnight. The volume of the mixture was concentrated to $\sim 50 \mathrm{~mL}$. The precipitate formed was filtered, washed with light petroleum, and dried under vacuum. Orange-red crystals of $\mathbf{6} \cdot \mathrm{ClO}_{4}$ gradually formed upon slow diffusion of diethyl ether into a DMF solution $(4 \mathrm{~mL})$ of the crude product. The crystals were filtered, washed with diethyl ether, and dried under vacuum. Yield: $29 \mathrm{mg}(7.6 \%)$. IR $(\mathrm{KBr})\left(\mathrm{cm}^{-1}\right)$ : $2930 \mathrm{w}$, 1903 vs, 1893 vs, 1833 vs, 1820 vs, 1659 vs, 1647 vs, 1602 m, 1480 m, 1438 m, 1385 m, 1331 w, 1261 w, 1154 m, 1091 vs, 1015 m, 955 w, 905 w, 822 w, 804 w, 764 m, 679 m, 661 m, 624 m, $589 \mathrm{~m}, 418 \mathrm{~m}$. UV/vis $\lambda_{\max }, \mathrm{nm}\left(\epsilon_{\max }\right): 388\left(\mathrm{sh}, 0.676 \times 10^{3}\right), 282$ (sh, $\left.4.028 \times 10^{3}\right)$. Anal. $\mathrm{C}_{30} \mathrm{H}_{35} \mathrm{ClMn}_{2} \mathrm{~N}_{7} \mathrm{O}_{8}$ (766.98) (\%): calcd: C, 46.98; H, 4.60; N, 12.78; found: C, 45.49; H, 4.69; N, 12.39 .

Calculation Details. All calculations were carried out with $\mathrm{DFT}^{21}$ by using the Gaussian 98 and Gaussian 03 package of programs. ${ }^{32}$ It is well-known that DFT is able to provide valuable answers to a variety of chemical problems. Nevertheless, one should take into account that the choice of the particular functional used as well as the basis set used can affect the results significantly. ${ }^{33,34}$ In the case of open-shell systems, and especially for transition-metal compounds, pure density functionals favor low-spin states, whereas hybrid functionals usually predict the high-spin state as the lowest energy state. ${ }^{34}$ Thus, our investigations on the neutral complexes 3 and $\mathbf{5}$ as well as on their monocations $\mathbf{3}^{+}$and $\mathbf{5}^{+}$were carried out with the hybrid $\mathrm{B} 3 \mathrm{LY} \mathrm{P}^{22}$ and pure $\mathrm{BP} 86^{23}$ functionals and the allelectron basis sets with and without polarization functions. Both functionals are commonly used for the investigation of transitionmetal compounds, also comprising the cases of open-shell mixedvalent species. ${ }^{15 \mathrm{~b}, 28}$ All computations employed the unrestricted
Kohn-Sham formalism. The basis sets used are of valence triple- $\zeta$ quality: 6-311G or 6-311G* for the main group elements ${ }^{24}$ and Wachter's $(14 \mathrm{~s} 9 \mathrm{p} 5 \mathrm{~d}) /[9 \mathrm{~s} 5 \mathrm{p} 3 \mathrm{~d}]$ or $(14 \mathrm{~s} 9 \mathrm{p} 5 \mathrm{~d} 1 \mathrm{f}) /[9 \mathrm{~s} 5 \mathrm{p} 1 \mathrm{~d} 1 \mathrm{f}]\left(\alpha_{\mathrm{f}}=\right.$ 0.96 ) for the Mn atoms. ${ }^{25}$ For the BP96 functional we used the resolution-of-the-identity (RI) approximation. ${ }^{35}$ This approach expands the density in a set of atom-centered functions and takes advantage of the fitting of the Coulomb potential. The auxiliary basis sets needed for RI approximation were generated automatically according to the procedures implemented in Gaussian 03. The RI approximation largely increases the performance of pure DFT treatments without significantly decreasing accuracy. With both functionals and basis sets, we performed geometry optimizations for the neutral complexes $\mathbf{3}$ and $\mathbf{5}$ in their sextet electronic state $\left({ }^{6} \mathbf{3},{ }^{\mathbf{6}}\right)$ as well as for the monocations in their septet $\left({ }^{\mathbf{7}} \mathbf{3}^{+}, \mathbf{7}^{+}\right)$ and quintet $\left({ }^{\mathbf{5}^{+}}\right)$states. Single-point calculations were also carried out for the doublet state $\mathbf{2} \mathbf{3}$ with the optimized geometry of the sextet state, ${ }^{\mathbf{6}}$. The optimized structures correspond to fully converged geometries with gradients and displacements below the threshold implemented in the Gaussian programs. Geometry optimizations were followed by vibrational frequency analyses. Harmonic frequencies were computed analytically, and if not stated explicitly, they were used without scaling. All optimized structures have all real frequencies and represent minima on their potential energy surfaces. For graphical displays we used the MOLEK-9000, Molden, and GaussView programs. ${ }^{36}$

(32) (a) Frisch, M. J.; Trucks, G. W.; Schlegel, H. B.; Scuseria, G. E.; Robb, M. A.; Cheesmann, J. R.; Zakrzewski, V. G.; Montgomery, J. A.; Jr., Stratmann, R. E.; Burant, J. C.; Dapprich, S.; Millam, J. M.; Daniels, A. D.; Kudin, K. N.; Strain, M. C.; Farkas, O.; Tomasi, J.; Barone, V.; Cossi, M.; Cammi, R.; Mennuci, B.; Pomelli, C.; Adamo, C.; Clifford, S.; Ochterski, J.; Peterson, G. A.; Ayala, P. Y.; Cui, Q.; Morokuma, K.; Salvador, P.; Dannenberg, J. J.; Malick, D. K.; Rabuck, A. D.; Raghavachari, K.; Foresmann, J. B.; Cioslowski, J.; Oritz, J. V.; Baboul, A. G.; Stefanov, B. B.; Liu, G.; Liashenko, A.; Piskorz, P.; Komaromi, I.; Gomperts, R.; Martin, R. L.; Fox, D. J.; Keith, T.; Al-Laham, M. A.; Peng, C. Y.; Nanayakkara, A.; Challacimbe, M.; Gill, P. M. W.; Johnson, B.; Chen, W.; Wong, M. W.; Andres, J. L.; Gonzales, C.; Head-Gordon, M.; Replogle, E. S.; Pople, J. A. Gaussian 98, Revision A11; Gaussian Inc.: Pittsburgh, PA, 2001. (b) Frisch, M. J.; Trucks, G. W.; Schlegel, H. B.; Scuseria, G. E.; Robb, M. A.; Cheeseman, J. R.; Montgomery, J. A., Jr.; Vreven, T.; Kudin, K. N.; Burant, J. C.; Millam, J. M.; Iyengar, S. S.; Tomasi, J.; Barone, V.; Mennucci, B.; Cossi, M.; Scalmani, G.; Rega, N.; Petersson, G. A.; Nakatsuji, H.; Hada, M.; Ehara, M.; Toyota, K.; Fukuda, R.; Hasegawa, J.; Ishida, M.; Nakajima, T.; Honda, Y.; Kitao, O.; Nakai, H.; Klene, M.; Li, X.; Knox, J. E.; Hratchian, H. P.; Cross, J. B.; Bakken, V.; Adamo, C.; Jaramillo, J.; Gomperts, R.; Stratmann, R. E.; Yazyev, O.; Austin, A. J.; Cammi, R.; Pomelli, C.; Ochterski, J. W.; Ayala, P. Y.; Morokuma, K.; Voth, G. A.; Salvador, P.; Dannenberg, J. J.; Zakrzewski, V. G.; Dapprich, S.; Daniels, A. D.; Strain, M. C.; Farkas, O.; Malick, D. K.; Rabuck, A. D.; Raghavachari, K.; Foresman, J. B.; Ortiz, J. V.; Cui, Q.; Baboul, A. G.; Clifford, S.; Cioslowski, J.; Stefanov, B. B.; Liu, G.; Liashenko, A.; Piskorz, P.; Komaromi, I.; Martin, R. L.; Fox, D. J.; Keith, T.; Al-Laham, M. A.; Peng, C. Y.; Nanayakkara, A.; Challacombe, M.; Gill, P. M. W.; Johnson, B.; Chen, W.; Wong, M. W.; Gonzalez, C.; Pople, J. A. Gaussian 03, Revision C.02; Gaussian, Inc.: Wallingford CT, 2004

(33) Koch, W.; Holthausen, M. C. A Chemist's Guide to Density Functional Theory; Wiley-VCH: Weinheim, Germany, 2000 and bibliography therein.

(34) (a) Reiher, M.; Salomon, O.; Hess, B. Theor. Chem. Acc. 2001, 107, 48-55. (b) Salomon, O.; Reiher, M.; Hess, B. J. Chem. Phys. 2002, 117, 4729-4737. (c) Reiher, M. Inorg. Chem. 2002, 41, 6928-6935

(35) (a) Dunlap, B. I. J. Chem. Phvs. 1983, 78, 3140-3142. (b) Eichkorn, K.; Treutler, O.; Ohm, H.; Häser, M.; Ahlrichs, R. Chem. Phys. Lett. 1995, 242, 652-660. (c) Treutler, O.; Ahlrichs, R. J. Chem. Phvs. 1995, 102, 346-354. (d) Dunlap, B. I. J. Mol. Struct.: THEOCHEM 2000, 529, 37-40.

(36) (a) Bischof, P. Molek-9000, Universität Heidelberg: Heidelberg, Germany, 2000. (b) Schaftenaar, G.; Noordik, J. H. Molden: a preand postprocessing program for molecular and electronic structures, J. Comput.-Aided Mol. Des. 2000, 14, 123-134; (c) GaussViewW; Gaussian, Inc.: Pittsburgh, PA, 2000. 
Table 8. Crystal Data and Refinement Details for 3, 4, 5. $\mathrm{CH}_{2} \mathrm{Cl}_{2}$, and $\mathbf{6} \cdot \mathrm{ClO}_{4}$

\begin{tabular}{|c|c|c|c|c|}
\hline & 3 & 4 & 5. $\mathrm{CH}_{2} \mathrm{Cl}_{2}$ & $6 \cdot \mathrm{ClO}_{4}$ \\
\hline formula & $\mathrm{C}_{24} \mathrm{H}_{21} \mathrm{ClMn}_{2} \mathrm{~N}_{5} \mathrm{O}_{2}$ & $\mathrm{C}_{27} \mathrm{H}_{28} \mathrm{BrMn}_{2} \mathrm{~N}_{6} \mathrm{O}_{3}$ & $\mathrm{C}_{26} \mathrm{H}_{24} \mathrm{Mn}_{2} \mathrm{~N}_{5} \mathrm{O}_{4} \cdot \mathrm{CH}_{2} \mathrm{Cl}_{2}$ & $\mathrm{C}_{30} \mathrm{H}_{35} \mathrm{Mn}_{2} \mathrm{~N}_{7} \mathrm{O}_{4}^{+}, \mathrm{ClO}_{4}^{-}$ \\
\hline$M_{\mathrm{r}}$ & 556.79 & 674.34 & 665.31 & 766.98 \\
\hline crystal size $[\mathrm{mm}]$ & $0.43 \times 0.32 \times 0.22$ & $0.49 \times 0.32 \times 0.21$ & $0.32 \times 0.18 \times 0.11$ & $0.22 \times 0.20 \times 0.18$ \\
\hline crystal system & monoclinic & triclinic & triclinic & triclinic \\
\hline space group & $P 2_{1} / c$ (No. 14$)$ & $P \overline{1}$ (No. 2$)$ & $P \overline{1}$ (No. 2$)$ & $P \overline{1}($ No. 2$)$ \\
\hline$a[\AA]$ & $14.6104(4)$ & $9.2302(7)$ & $9.2710(3)$ & $12.4810(4)$ \\
\hline$b[\AA]$ & $9.1920(3)$ & $12.3696(9)$ & $11.2919(3)$ & $16.1969(6)$ \\
\hline$c[\AA]$ & $17.5677(6)$ & $13.0842(10)$ & $14.4830(4)$ & $17.3766(6)$ \\
\hline$\alpha\left[^{\circ}\right]$ & 90 & $84.862(6)$ & $101.782(1)$ & $93.082(3)$ \\
\hline$\beta\left[^{\circ}\right]$ & $100.204(2)$ & $72.713(6)$ & $91.122(1)$ & $94.497(3)$ \\
\hline$\gamma\left[^{\circ}\right]$ & 90 & $82.590(6)$ & $103.841(2)$ & $107.938(3)$ \\
\hline$V\left[\AA^{3}\right]$ & $2322.00(13)$ & $1412.41(18)$ & $1437.40(7)$ & $3320.4(2)$ \\
\hline$\rho_{\text {calcd }}\left[\mathrm{g} \mathrm{cm}^{-3}\right]$ & 1.593 & 1.586 & 1.537 & 1.534 \\
\hline Z & 4 & 2 & 2 & 4 \\
\hline$F(000)[\mathrm{e}]$ & 1132 & 682 & 678 & 1580 \\
\hline$\mu\left[\mathrm{mm}^{-1}\right]$ & $1.235(\mathrm{Mo} \mathrm{K} \alpha)$ & $2.348(\mathrm{Mo} \mathrm{K} \alpha)$ & $9.212(\mathrm{Cu} \mathrm{K} \alpha)$ & 0.901 (Mo K $\alpha)$ \\
\hline$h k l$ range & $\pm 17, \pm 10, \pm 20$ & $\pm 10, \pm 14, \pm 15$ & $\pm 10, \pm 12, \pm 16$ & $\pm 14, \pm 19,-19-20$ \\
\hline$\theta$ range $\left[{ }^{\circ}\right]$ & $2.51-24.79$ & $1.63-24.77$ & $3.12-60.27$ & $1.70-24.82$ \\
\hline measured reflns & 68606 & 15148 & 7380 & 68793 \\
\hline unique reflns $\left[R_{\text {int }}\right]$ & $3923[0.0440]$ & $4807[0.0350]$ & $4199[0.0258]$ & $11395[0.0507]$ \\
\hline observed reflns $I>2 \sigma(I)$ & 3834 & 4510 & 3606 & 10139 \\
\hline refined parameters & 307 & 354 & 398 & 883 \\
\hline $\mathrm{R} 1$ & 0.0262 & 0.0248 & 0.0617 & 0.0320 \\
\hline wR2 (all data) & 0.0702 & 0.0614 & 0.1891 & 0.0775 \\
\hline GOF & 1.097 & 1.046 & 1.058 & 1.033 \\
\hline resid el dens $\left[\mathrm{e} \AA^{-3}\right]$ & $0.384 /-0.346$ & $0.371 /-0.294$ & $1.379 /-0.486$ & $0.784 /-0.557$ \\
\hline
\end{tabular}

X-ray Crystallography. X-ray data (Table 8) for $\mathbf{3 , 4}$, and $\mathbf{6} \cdot$ $\mathrm{ClO}_{4}$ were collected on a Stoe IPDS II diffractometer (monochromated Mo K $\alpha$ radiation, $\lambda=0.71073 \AA$, $\omega$ scans) at $-140{ }^{\circ} \mathrm{C}$, and data for $\mathbf{5} \cdot \mathrm{CH}_{2} \mathrm{Cl}_{2}$ was collected on a Bruker SMART 6000 $4 \mathrm{~K}$ CCD diffractometer (monochromated $\mathrm{Cu} \mathrm{K} \alpha$ radiation, $\lambda=$ $1.54178 \AA, \varphi$ and $\omega$ scans) at $0{ }^{\circ} \mathrm{C}$. The structures were solved by direct methods and refined on $F^{2}$ using all reflections with SHELX97. ${ }^{37}$ All non-hydrogen atoms were refined anisotropically. Hydrogen atoms were placed in calculated positions and assigned to an isotropic displacement parameter of $0.08 \AA^{2}\left(\mathbf{3}, \mathbf{4}\right.$, and $\left.\mathbf{6} \cdot \mathrm{ClO}_{4}\right)$; for $\mathbf{5} \cdot \mathrm{CH}_{2} \mathrm{Cl}_{2}$ a riding model was used. The chlorine atoms of a $\mathrm{CH}_{2} \mathrm{Cl}_{2}$ solvent molecule in $\mathbf{5} \cdot \mathrm{CH}_{2} \mathrm{Cl}_{2}$ are disordered over approximately three positions and were therefore refined with fixed occupancy factors of 0.33 for each position. Three oxygen atoms of one $\mathrm{ClO}_{4}^{-}$anion in $\mathbf{6}$ are disordered over approximately two positions, with occupancy factors of $0.773(3)$ and $0.227(3)$. All $\mathrm{Cl}-\mathrm{O}$ and $\mathrm{O} \cdots \mathrm{O}$ distances as well as the displacement parameters

(37) (a) Sheldrick, G. M. SHELXL-97: Program for Crystal Structure Refinement; Universität Göttingen, Göttingen, Germany, 1997. (b) Sheldrick, G. M. SHELXS-97: Program for Crystal Structure Solution; Universität Göttingen, Göttingen, Germany, 1997.

(38) X-RED, Stoe \& Cie GmbH: Darmstadt, Germany, 2002. of opposite oxygen atoms were restrained to be equal. Face-indexed absorption corrections for 3 ( $\mathrm{max} / \mathrm{min}$ transmission $0.8684 / 0.6304)$, and 4 ( $\mathrm{max} / \mathrm{min}$ transmission $0.7688 / 0.4281)$ were performed numerically with the program X-RED. ${ }^{38}$ The geometrical aspects of the structures were analyzed by using the PLATON program. ${ }^{39}$

Acknowledgment. Support of this work from the Fonds der Chemischen Industrie (F.M.) is gratefully acknowledged. I.H.-K. thanks the SFB 424 (Molekulare Orientierung als Funktionskriterium in chemischen Systemen) for financial support.

Supporting Information Available: Crystallographic data, in $\mathrm{CIF}$ format, for $\mathbf{3 , 4 , 5}$, and $\mathbf{6}$. UV/vis spectroscopic changes during the gradual oxidation of $\mathbf{5} \rightarrow \mathbf{5}^{+}$(Figure S1). This material is available free of charge via the Internet at http://pubs.acs.org.

IC0503683

(39) (a) Spek, A. L. Acta Crystallogr. 1990, A46, C34. (b) Spek, A. L. PLATON: A Multipurpose Crystallographic Tool; Utrecht University: Utrecht, The Netherlands, 2003. 